Portland State University

PDXScholar

Spring 4-14-2017

\title{
A Pilot Study on Methods to Introduce Teachers to New Science Standards
}

Noelle Frances Garcia Niedo

Portland State University

Follow this and additional works at: https://pdxscholar.library.pdx.edu/open_access_etds

Part of the Elementary Education Commons, and the Science and Mathematics Education Commons Let us know how access to this document benefits you.

\section{Recommended Citation}

Niedo, Noelle Frances Garcia, "A Pilot Study on Methods to Introduce Teachers to New Science Standards" (2017). Dissertations and Theses. Paper 3531.

https://doi.org/10.15760/etd.5415

This Thesis is brought to you for free and open access. It has been accepted for inclusion in Dissertations and Theses by an authorized administrator of PDXScholar. Please contact us if we can make this document more accessible: pdxscholar@pdx.edu. 
A Pilot Study on Methods to Introduce Teachers to New Science Standards

by

Noelle Frances Garcia Niedo

A thesis submitted in partial fulfillment of the requirements for the degree of

Master of Science in Teaching

in

General Science

Thesis Committee:

William Becker, Chair

Stephanie Wagner

Cary Sneider

Gabe Sheoships

Portland State University

2017 
(C) 2017 Noelle Frances Garcia Niedo 


\begin{abstract}
With the recent adoption of the Next Generation Science Standards in Oregon, there is a great need for teachers to be trained to effectively implement the three dimensions of the Next Generation Science Standards (NGSS) in their teaching. Time and location are the largest constraining factors that affect teacher participation in professional development trainings. To address this constraint, Tryon Creek State Park offered a NGSS professional development training opportunity for teachers that was integrated within a field trip that they took their students on. Before the field trip, teachers were introduced to the NGSS through a set of NGSS pre-field trip materials which informed them about the NGSS and how aspects of it would be integrated into their students' field trip. Teachers accompanied their students on a two-hour long field trip at Tryon Creek State Park where teachers observed nature guides model NGSS-aligned activities for the students. My research aimed to answer the following question: How will an informal science education program at Tryon Creek State Park affect K-2 teachers' awareness of the Next Generation Science Standards? Outcomes were measured through a pre/post retrospective survey and follow-up interviews. On the survey teachers reported little awareness of the three dimensions of the NGSS and very few of the teachers increased their understanding after the treatment. On the other hand, most had a high level of awareness and confidence in teaching factual information supporting the NGSS prior to treatment, resulting in a ceiling effect. Interviews suggested that few teachers read the materials sent in advance of the field trip, but teachers who did read the materials indicated increases in understanding of the NGSS. During the field trip several of the nature guides were effective in modeling science and engineering practices. These findings suggest that this method of professional development is promising, but needs further refinement.
\end{abstract}




\section{Dedication}

For the people of American Samoa 


\section{Table of Contents}

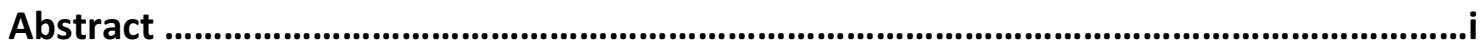

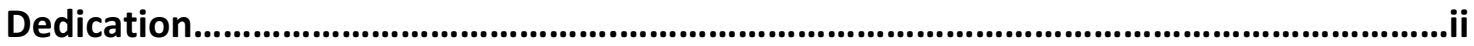

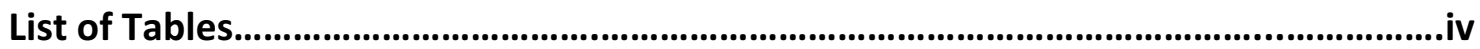

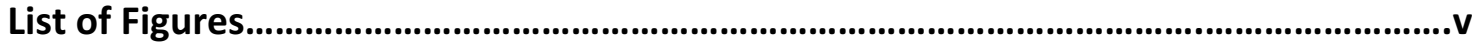

\section{Chapter 1}

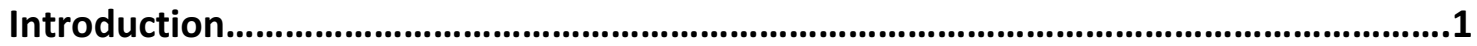

\section{Chapter 2}

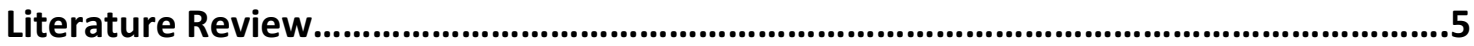

\section{Chapter 3}

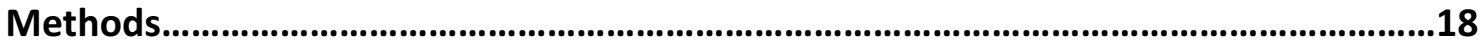

\section{Chapter 4}

Results

Chapter 5

Discussion.

\section{Chapter 6}

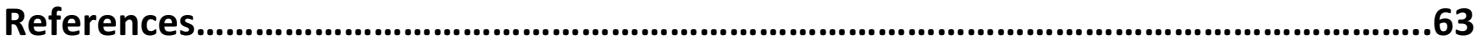

\section{Appendices}

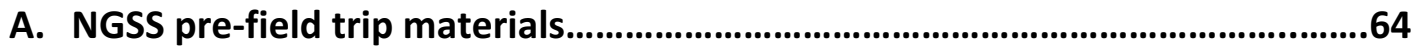

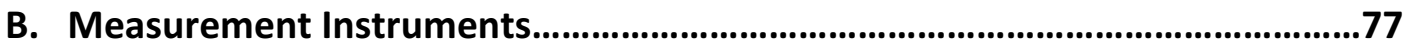

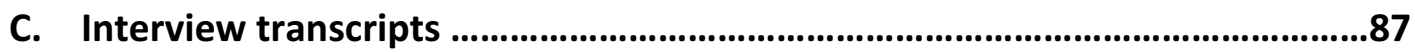




\section{List of Tables}

Table 1. Teacher Awareness and Confidence in Teaching Disciplinary Core Ideas Before and After Treatment

Table 2. Teacher Awareness and Confidence in Teaching Science and Engineering

Practices Before and After Treatment

Table 3. Teacher Awareness and Confidence in Teaching Crosscutting Concepts Before and After Treatment .34

Table 4. Teacher Awareness of NGSS General Knowledge Before and After

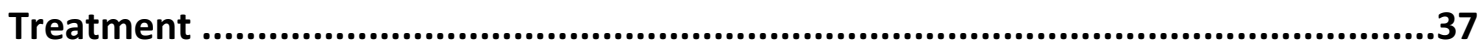

Table 5. Activities each teacher reporting seeing on the field trip ..............................41 


\section{List of Figures}

Figure 1. Teacher awareness and confidence in teaching Disciplinary Core Idea prior to treatment $(n=17)$ .28

Figure 2. Teacher awareness and confidence in teaching Science and Engineering Practices prior to treatment $(n=17)$ 31

Figure 3. Teacher awareness and confidence in teaching Crosscutting Concepts prior to Treatment $(n=17)$ .34

Figure 4. Teacher awareness of general knowledge of NGSS prior to treatment $(n=17)$ .36

Figure 5. Total number of statements each teacher reported an increase in awareness or confidence after treatment .38

Figure 6. Total number of teachers that reported engaging in each NGSS pre-field trip material

$(n=17)$

Figure 7. Total number of teachers that reported seeing each NGSS activity on the field trip $(n=17)$ .40

Figure 8. Number of teachers that reported which part of the field trip helped them to understand the Disciplinary Core Idea: Structure and Function $(n=17)$ .41

Figure 9. Number of teachers that reported which activities they saw the science and engineering practice of constructing explanations $(n=17)$.. 
Figure 10. Number of teachers that reported which activities they saw the Science and

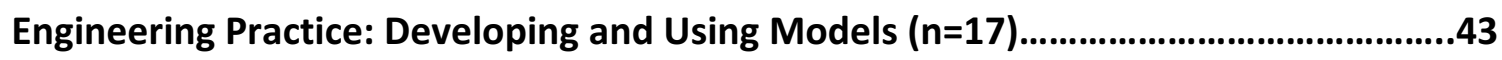




\section{Introduction}

The sweet aroma of the Western Red Cedar, the sound of the Pacific Wren's melodic tune, the sight of Pileated Woodpeckers hammering holes into the trees, the feel of the gentle, misty rain. This isn't your typical classroom. But teachers will extend teaching to outside of their classroom walls and take their students on field trips to have experiences such as these at Tryon Creek State Park. Tryon Creek State Park, located in SW Portland, Oregon conducts a Field Trip Program which offers educational experiences for kindergarten through elementary students year around. Trained volunteer nature guides facilitate various themed field trips, which explore topics such as animals, insects, plants, and watersheds.

While learning in the classroom has its benefits, there is something valuable about experiencing the natural world first hand that pictures in textbooks or videos about the natural world can't bring, making field trips to Tryon Creek a unique and memorable place to learn for both teachers and students alike. Tryon Creek's Field Trip Program is a chance for teachers to connect science to the real world, which teachers have reported were among their top needs in professional development (Chval, Abell, Pareja, Musikul, \& Ritzka, 2007). Through hands-on activities, group collaboration, and direct observations facilitated by trained nature guides, teachers help students make connections to key scientific concepts and gain ideas about how activities can be incorporated in the classroom. 
All field trip programs at Tryon Creek are aligned with the Next Generation Science Standards (NGSS), the most recently developed set of standards that that has been adopted to guide $\mathrm{K}-12$ schools in sixteen states, including Oregon, in the areas of science (NGSS Lead States, 2013). What sets the NGSS apart from previous science standards is that its foundation is built on three dimensions: Disciplinary Core Ideas, Crosscutting Concepts, and Science and Engineering Practices. Disciplinary Core Ideas consist of content from disciplines in the Life Sciences, Physical Sciences, Earth and Space Sciences, and Engineering. Crosscutting Concepts are ideas that can be found in all science disciplines and bridge science disciplines together. Science and Engineering Practices are ways in which students apply scientific content knowledge in a way that reflects how science is conducted in a real world setting.

The field trip program studied in this project was called the Adaptable Animals Program. The program aimed to support NGSS Performance Expectations at the kindergarten, first, and second grade level by developing a deeper understanding of how plants and animal parts (structures) allow them to live (function) successfully in the Tryon forest. Adaptable Animals, in particular, focused on teaching the Disciplinary Core Idea of Structure and Function in Living Organisms, the Crosscutting Concept of Structure and Function, and the Science and Engineering Practices of Developing and Using Models and Constructing Explanations.

Because the NGSS was only released in 2013, there is limited research on learning and teaching using the three areas of NGSS. With the recent adoption, teachers need to 
be trained to effectively implement the three areas of NGSS in their teaching in order to help students connect science to the real world and develop a conceptual understanding in science.

Time and location are the largest constraining factors that affect teacher participation in professional development trainings (Chval et al., 2007). Non-formal education programs have played a role in teacher professional development (Melber and Cox - Peterson, 2005; Holliday, J. Lederman, \& N. Lederman, 2014; Sackes, Trundle, \& Krissek, 2011; Anderson, Kisiel, \& Storksdieck, 2006). To address this constraint, Tryon Creek State Park offered a NGSS professional development training opportunity for teachers that was integrated within a field trip that they took their students on. Before the field trip, teachers were introduced to the NGSS through a set of NGSS pre-field trip materials which informed them about the NGSS and how aspects of it would be integrated into their students' field trip. Teachers then accompanied their students on a two-hour long field trip at Tryon Creek State Park where teachers observed nature guides model NGSS-aligned activities for the students.

My research aims to answer the following question: How will an informal science education program at Tryon Creek State Park affect K - 2 teachers' awareness of the three dimensions of the NGSS and confidence in teaching science concepts? The informal science education program studied was the Adaptable Animals Field Trip Program which was conducted at Tryon Creek State Park. The participants of the study were K-2 teachers who accompanied their students on the Adaptable Animals Field Trip. 
The treatment of my research included 1 ) the materials that were emailed to the teachers prior to attending the field trip which informed them about the NGSS and how it will be integrated into the field trip and 2) the NGSS aligned field trip program experience.

Outcomes were measured through a pre/post retrospective survey and followup interview. After attending the field trip, each teacher was invited to complete a survey which asked them to report how they felt about their understanding of the three dimensions of the NGSS before the field trip and after the field trip. The survey also asked teachers to report which of the pre-materials they read or used before attending the field trip. All teachers who completed a survey were invited to participate in a follow-up interview.

Although there is little objective research on the effectiveness of Tryon Creek's Field Trip Program, I predicted that the Field Trip Program would help teachers gain an awareness and confidence in teaching the three dimensions of the NGSS. For example, in looking at the structure of a woodpecker beak, teachers would be able to see how its structure allows a woodpecker to make holes on trees. Or, in observing the structure of a seed, teachers would be able to see which structures help a seed survive. Seeing examples of instruction should help teachers gain a better understanding of how to integrate aspects of the Next Generation Science Standards. The act of participating alone does not give teachers the tools they need to be able to teach NGSS. Therefore, materials were provided to help teachers with the higher-level skills needed to teach 
these. In other words, participation in the field trip is not sufficient and meta-cognition is essential. Since teachers have these experiences in the Adaptable Animals Field Trip and accompanying materials, my hypothesis was that they would become more aware of three dimensional learning as called for in the NGSS, and more confident in teaching science.

\section{Literature Review}

With the recent adoption of the Next Generation Science Standards in Oregon, local school districts are expected to develop their own implementation plans and professional development opportunities regarding the new standards. Currently, there are few professional development opportunities for teachers to receive training regarding the NGSS and many teachers are expected to find resources independently. Informal education programs have played a role in teacher professional development. The Field Trip Program at Tryon Creek State Park aims to support this need by providing teachers with information regarding the NGSS and an opportunity to see how the NGSS is integrated into a two-hour field trip.

The bodies of literature that supports this research project falls into four areas: 1) science teachers' professional development needs 2) the goals of the Next Generation Science Standards, 3) the current state of NGSS in Oregon, and 4) the role of informal science education programs. This literature review synthesizes these bodies of literature and discusses how the literature informs the project.

\section{Science teachers' professional development needs}


One of the things I wanted to know as background to the study was what science teachers' professional development needs were. Chval et al. (2007) undertook a study of middle and high school science and mathematics teachers to identify their 1) experiences, 2) needs, 3) expectations, and the 4) constraints on their ability to attend professional development trainings (PD). The researchers developed a survey in which teachers responded to questions regarding these four topics. The researchers administered the survey to 1000 science and mathematics teachers in the state of Missouri. Among the top needs reported were developing critical thinking in science/math; connecting science/math to the real world; and developing conceptual understanding in science/math. The majority of teachers in the study expected PD to provide subject specific topics that are aligned with state standards and tests and are focused on the content and grade level they teach. Teachers also expected PD to be convenient in terms of location and schedule, as time conflict was the largest constraining factor that affected teacher participation in PD. However, the research findings demonstrated that teachers' experiences in PD did not meet their PD needs and expectations. The research suggests that since school districts do not have the resources to design, implement, and fund PD, school districts should make use of other state resources to develop a coherent PD system.

Zhang et al. (2015) also identified science teachers' PD needs by conducting a study of $\mathrm{K}-12$ science teachers in order to understand what science topics they perceived they needed improvement on and why. The researchers developed a survey 
that asked teachers to select the two major science unit topics from their teaching that they would like to improve through the PD. The survey was administered to 118 science teachers who participated in a PD program for over 3 years. The researchers found that across grade levels, the most common life science topics selected were ecosystems, plants and animals, and the human body. Similar to the finding of Chval et al. (2007), the researchers found that teachers needed to improve students' conceptual understanding and needed to connect the science topics to real life. Teachers reported that they needed to improve their instructional strategies by incorporating inquiry-based approaches and aligning their teaching with new curriculum standards; and on developing assessments that would effectively evaluate student learning and improve student performance in standardized tests. The teachers reported that they needed to improve in these areas because: (1) they were not areas they had been trained in, (2) they were too difficult for students to learn, (3) they were topics that they lacked inquiry-based or problem-based instructional approaches, and (4) they were topics that teachers needed to align with new curriculum standards.

In both studies, among science teachers' top needs included connecting science to the real world, developing a conceptual understanding of specific science topics, and aligning their teaching with new state standards. The largest constraining factor affecting teacher participation in PD was time conflict: teachers needed PD to be convenient in terms of location and schedule. 
These findings imply that teachers need a professional development program that helps them to connect science to the real world, develop a conceptual understanding in science, and one that is convenient in terms of location and schedule. My project at Tryon Creek State Park aims to address these needs and constraining factors.

\section{Goals of the Next Generation Science Standards}

The Next Generation Science Standards (NGSS) is the most recently - developed set of standards that were created to guide K - 12 schools in the United States in the areas of science (NGSS Lead States, 2013). Sixteen states have adopted the NGSS, including Oregon, where this study is located. What sets the NGSS apart from previous science standards is the idea that students need to integrate three dimensionsDisciplinary Core Ideas, Crosscutting Concepts, and Science and Engineering Practicesin order to be scientifically literate. In adopting NGSS standards, the goal is for students to be able to connect science to the real world and develop a conceptual understanding of science as a way of understanding the natural world. There are 12 Disciplinary Core Ideas, divided into 44 sub-ideas, which consist of content from disciplines in the Life Sciences, Physical Sciences, Earth and Space Sciences, and Engineering. There are 7 Crosscutting Concepts, which are ideas that can be found in all science disciplines and bridge science disciplines together. There are 8 Practices, which are ways in which students are to apply scientific content knowledge. Students need to integrate these three dimensions in order to be scientifically literate. 
According to the National Research Council (2012), the NGSS aims to reflect a new vision to improve science education and student achievement in the following ways:

1. K-12 science education should reflect the interconnected nature of science as it is practiced and experienced in the real world.

2. The NGSS are student performance expectations - NOT curriculum.

3. The science concepts in the NGSS build coherently from $\mathrm{K}-12$.

4. The NGSS focus on deeper understanding of content as well as application of content.

5. Science and engineering are integrated in the NGSS from kindergarten through twelfth grade.

6. The NGSS are designed to prepare students for college, careers, and citizenship.

7. The NGSS and Common Core State Standards (English Language Arts and Mathematics) are aligned.

Two goals of the NGSS mentioned above are to connect science to the real world and to focus on deeper conceptual understanding of content. Although studies conducted by Chval et al. (2007) and Zhang et al. (2015) did not look at NGSS standards specifically, they identified a need for PD around the subject of how to connect science to the real world and gain a conceptual understanding in science. To achieve this goal, the NGSS emphasizes that students integrate and engage in the three dimensions of NGSS: Disciplinary Core Ideas, Crosscutting Concepts, and Science and Engineering Practices. By focusing on a smaller set of Disciplinary Core Ideas, the NGSS aims to help 
students develop a deeper understanding of core ideas in science, allowing for more time to apply their scientific content knowledge to real world situations and connect their knowledge across science disciplines. Instead of focusing on the memorization of facts, the NGSS aims for students to apply what they have learned to solve problems and in new situations. The goals of the NGSS implies the potential for a NGSS aligned curriculum to address the needs of teachers in science. The field trip program at Tryon Creek State Park is aligned with the NGSS.

\section{Current State of NGSS in Oregon}

With the recent adoption of the Next Generation Science Standards in several states, there is a great need for teachers to be trained to effectively implement the three dimensions of the NGSS in their teaching in order to help students to connect science to the real world and to develop a conceptual understanding in science. In Oregon, there is currently a lack of funding to implement the NGSS at the state-wide level (J. Rumage, personal communication, September 26, 2016). This includes funding to conduct professional development opportunities for teachers regarding the NGSS. As a result, it is left to local school districts to develop their own transition plans and professional development opportunities for teachers regarding the implementation of the NGSS. The advantage of districts being responsible for their own implementation plan is that they have the opportunity to focus on their unique district needs and priorities regarding science education. The Oregon Department of Education provides guidance and suggestions on how districts should be implementing the NGSS. According to Jamie 
Rummage, Oregon Department of Education, the current state of implementation and teacher professional development regarding the NGSS varies from school district to school district (personal communication, September 26, 2016). Some school districts have been developing their implementation plans since the standards were created while other school districts are just beginning to create their implementation plans.

The disadvantage falls on the teacher. In many school districts, it is the responsibility of the educator to reach out on their own to figure out where that training can come from. However, according to the study conducted by Chval et al. (2007), the largest constraining factor affecting teacher participation in PD was time conflict. With a full schedule of a teacher, attending PD trainings can be an issue. Teachers need PD trainings to be convenient in terms of location and schedule.

The Oregon Department of Education provides a website for educators that contains online resource pages and video clips regarding general ideas about the Next Generation Science Standards (Oregon STEM Website 2016). The resources on the website do not necessarily address the specific steps needed to take during this transition to the new standards. Unfortunately, there are few face to face opportunities for teachers to receive professional development regarding the NGSS. One face to face opportunity that addresses the NGSS is conducted through the Math Science Partnership Grant in the Portland Metro Area. This grant is focused on helping elementary educators transition to the NGSS with the hope to develop NGSS elementary 
leaders. However, the grant is limited to 70 teachers, leaving many educators without any professional development regarding the NGSS.

Because the NGSS was only released in 2013, there is limited research on learning and teaching using the three areas of NGSS. There is not much research done on the effectiveness of the NGSS so far. My study will be on the ground floor and aims to help fill in a large gap.

\section{Role of informal science education programs}

There is a substantial amount of literature that shows how informal science education programs have played a role in teacher professional development. Informal science education programs include museums, aquariums, and field based programs. Melber and Cox - Peterson (2005) conducted a study of elementary and secondary teachers to investigate the impact of three variations of professional development workshops set within informal (museum and field - based) learning environments on teachers' understanding of science content and processes, instructional practices, and awareness of museum and science field resources within the community. Each teacher participated in one of three variations of PD workshops. The first workshop was museum-based and took place at two natural history museums and an automotive museum; the second workshop was museum and field-based and took place at a natural history museum and a field site in the Santa Monica Mountains; the third workshop was field-based and took place at Red Rock Canyon State Park as a weekend camp out. Each workshop curriculum was developed by the same museum professional, had museum 
educators as workshop leaders, and included interaction with a museum scientist. Teachers participated in hands-on activities and were also given curricular materials that translated workshop activities into classroom lessons. The length of each workshop was a total of 15 hours. The researchers gave a retrospective survey to teachers at the end of each workshop, which measured teachers' understanding of science content and processes, instructional practices, and what elements of the workshop teachers found most helpful. The survey was administered to 54 teachers. They found that in each workshop, teachers increased their knowledge of science content. Teachers in the museum - based workshop gained more science content knowledge than the other two workshops. However, teachers in the museum - based workshop and the field - based workshop gained more science process knowledge and they reported that the element they found most helpful was the opportunity to interact with museum scientists (entomologist, paleontologist, and ornithologist). They found that in each workshop, teachers gained knowledge on how to conduct different classroom activity ideas for different topics.

Holliday et al. (2014) conducted a study of elementary and middle school science teachers to investigate the impact of exhibits on teachers' understanding of science content. Ninety-four teachers participated in one of three groups, each of which engaged with an exhibit in a different way. The first group engaged in a traditional guided tour in which teachers were asked to wear headphones and listen to an exhibit designer (who spoke into a wireless microphone) speak as he led the group through the 
exhibit, thereby making implicit connections to the science content. The second group engaged in a self-guided tour and were given three guiding questions to answer, also making implicit connections to the science content. The third group engaged in a worksheet as they explored the exhibit and were given the opportunity to discuss the worksheet questions with a PD staff member after, thereby addressing the science content in an explicit way. Teacher interactions with exhibits were video and audio recorded and analyzed. The researchers found that teachers who participated in the guided tour hardly engaged in discussion throughout the tour. They found that the majority teachers who had participated in a self-guided tour with guiding questions merely reacted to the novelty of the exhibit and did not engage in further discussion of the exhibit. They found that majority of teachers who had participated in completing the worksheet engaged in in - depth discussions that were related to content and pedagogy. The findings of this study suggest that when PD staff made explicit connections between exhibits and science content, teachers developed deeper understanding of content.

Sackes et al. (2011) conducted a study of pre $-\mathrm{K}$ to second grade teachers to investigate the impact of a four - day summer professional development program on teachers' knowledge of earth and space science concepts. Twenty-five teachers engaged in inquiry - based instruction and hands - on learning of earth and space science concepts. The researchers administered a pre and post - test consisting of multiple choice, short answer, open - ended questions, and drawings to measure teachers' 
conceptual understanding of earth and space science concepts before and after instruction. They found that teachers' test scores after instruction were significantly higher than their scores before instruction. These findings suggest that even a short term professional development program that addressed earth and space concepts can increase teachers' knowledge of these concepts.

I also wanted to learn how most teachers perceived field trips. Kisiel (2005) conducted a study to identify what motivated elementary teachers to take their classes on field trips to science museums and other science related sites. He developed a survey that consisted of closed and open-ended questions and administered it to a total of 115 teachers. Teachers' responses were coded and eight motivations were identified: to connect with curriculum, provide learning experiences, promote lifelong learning, foster interest and motivation, expose to new experiences, provide a change of setting, provide enjoyment or reward, and satisfy school expectations. The most commonly cited motivation for taking classes on field trips was "to connect with the curriculum" with about $90 \%$ of teachers citing this motivation. Further examination of this particular motivation revealed that teachers believed that field trips allowed for students to engage in authentic, firsthand experiences which they hope will help a student understand a topic more fully. The field trip conducted at Tryon Creek State Park is aligned with the Oregon's science standards, the Next Generations Science Standards.

Anderson et al. (2006) conducted a study to understand teachers' perspectives on field trips to museums because evidence shows that museum professionals often do 
not understand the needs of teachers. The study was conducted in three different countries: United States, Canada, and Germany. Over 200 teachers participated in the study in which teachers guided their classes on trips to a natural history museum, a science center, and a planetarium. Data was collected through open-ended surveys, interviews, and/or observations before, during, and after the field trip. Before the field trip, teachers were asked to report the major reason for conducting field trips. Just like in the study conducted by Kisiel (2005), $90 \%$ of teachers reported that the major reason was to "connect to curriculum." After the field trip, teachers were asked what made for a successful field trip. It is interesting to note that only $23 \%$ of teachers reported that connection to curriculum was a major motivation "despite the fact that this was stated as the motivation of the majority of the teachers." The majority of teachers stated that student enjoyment was the most important indicator of a successful field trip. This study pointed out this contradiction.

Findings suggest the following: 1) when PD staff made explicit connections between exhibits and science content, teachers developed deeper understanding of content, 2) the opportunity to interact with museum scientists was the most helpful element for most teachers, and 3) field trips can function as professional development, especially given the time constraints that make access to PD complicated. The field trip program at Tryon Creek State Park incorporates all of these.

To summarize: Elementary teachers have a number of needs and expectations that must be met in order for them to grow and improve their practices which in turn will 
help students to learn effectively. Among teachers' top needs in science are connecting science to the real world, developing conceptual understanding in science, and aligning their teaching with new state standards. Time conflict is the largest constraining factor that affects teacher participation in PD, and teachers expect PD to be convenient in terms of location and schedule and that time is used efficiently. However, studies show that these needs and expectations are not being addressed during their present professional development experiences.

The Next Generation Science Standards aim to address those needs of teachers to connect science to the real world and develop a conceptual understanding in science. But with the recent adoption of the Next Generation Science Standards in several states, there is a great need for teachers to be trained to effectively implement the three dimensions of NGSS in their teaching in order to help students to connect science to the real world and develop a conceptual understanding in science. Because the NGSS was only released in 2013 , there is limited research on learning and teaching using the three areas of NGSS.

Informal science education programs play a role in teacher professional development. Several studies have shown that informal science education programs have helped teachers increase their content knowledge of science and helped teachers align their teaching with new state standards. However, few studies have been found that address the need of teachers to develop a conceptual understanding in science and time constraints. 
Research findings in the three areas suggest the potential for an informal science education program to help teachers understand the three dimensions of the NGSS, which will address the need of teachers to connect science to the real world, develop conceptual understanding in science, and align their teaching with new state standards at a location and time that is convenient for them.

Given the time constraint teachers encounter which hinders them from attending professional development opportunities from the study conducted by Chval et al. (2007), my research proposes a professional development opportunity that is integrated into a field trip program that they accompany their students on. In this case, teachers are introduced to NGSS through a set of pre-materials which will prime their experience. I hope that this method can be a model for introducing the NGSS to teachers.

From the study conducted by Anderson et al. (2006), it is important to note that during the day of the field trip teachers were expected to connect the field trip to their curriculum independently without the explicit help of museum professionals. The study at Tryon Creek State Park differs from this study in that the program was created to reflect the Next Generation Science Standards and is facilitated by trained nature guides. In my study, I propose that if Tryon connects their programs to curriculum, then hopefully teachers would be able to connect it to curriculum. 
My research will focus on answering the question: In what ways will an informal science education program at Tryon Creek State Park affect $\mathrm{K}-2$ teachers' awareness and confidence in teaching the dimensions of the Next Generation Science Standards?

\section{Methods}

\section{Overview}

My research aims to answer the following question: How will an informal science education program affect K-2 teachers' awareness and confidence of the three dimensions of the Next Generation Science Standards (NGSS)? The informal science education program studied was the Adaptable Animals Field Trip Program which was conducted at Tryon Creek State Park. The participants of the study were K-2 teachers who accompanied their students on the Adaptable Animals Field Trip. The treatment of

my research included 1) pre-field trip materials regarding the NGSS that were emailed to the teachers prior to attending the field trip which informed them about the NGSS and how it would be integrated into the field trip and 2) the two-hour field trip program with NGSS aligned activities. Outcomes were measured through a survey and follow-up interview.

\section{Location and Program}

Tryon Creek State Park, an urban forest in Portland, OR, conducts a Field Trip Program which offers educational experiences for students from pre-school through fifth grade. The state park offers a variety of themed field trip programs which explore topics such as animals, insects, plants, streams, and watersheds. The field trip studied in 
this project was the Adaptable Animals Program. The program aimed to support NGSS Performance Expectations at the kindergarten, first, and second grade level by developing a deeper understanding of how plants and animal parts (structures) allow them to live (function) successfully in the Tryon forest. All field trip programs at Tryon Creek are aligned with the NGSS. Adaptable Animals, in particular, focused on teaching the Disciplinary Core Idea of Structure and Function in Living Organisms, the Crosscutting Concept of Structure and Function, and the Science and Engineering Practices of Developing and Using Models and Constructing Explanations.

\section{Field Trip Scheduling Process}

When scheduling the field trip, one teacher was decided to be "point person" to receive all emails from the field trip coordinator and send all emails to the rest of the teachers. Teachers registered by filling out a registration form indicating their date preferences, desired field trip program, school information, teacher contact information, grade level of students, number of students participating, and other logistical information such as transportation and lunch details. The teacher emailed the completed document to the Field Trip Coordinator. The Field Trip Coordinator was responsible for contacting the point teacher to finalize their dates and details. Tryon Creek's field trip program schedule fills up quickly and teachers registered their students for the field trip program three to four months in advance. Upon confirmation, the Field Trip Coordinator emailed the point teacher several documents regarding expectations, 
etiquette, chaperones, directions, parking, and a map of Tryon Creek to be forwarded to the rest of the teachers

\section{Participants}

All K-2 teachers who registered for the Adaptable Animals Program during the time of data collection in April, May, and June of the study year were invited to participate in my research survey. They were selected from a population of teachers who have registered for the Adaptable Animals Program at the time of data collection. There were a total of fifty-one K-2 teachers who registered for the Adaptable Animals Program, and they were all invited to participate in my research survey following the field trip. Teachers self-selected to participate in the study. All teachers who completed the survey were invited to participate in a follow-up interview. A total of 17 teachers selected to participate in the survey and 4 teachers agreed to be interviewed.

\section{Treatment 1: Pre-Field Trip Materials Regarding the NGSS}

Approximately one week before each teacher's scheduled field trip, the field trip coordinator sent each teacher an email regarding Tryon Creek State Park's recent work to align their Field Trip Programs with the NGSS. The purpose of this email was to inform the teachers about the NGSS and how it would be integrated into the field trip. The email contained a letter, program outline, and formative assessment probe. Included in the letter was a link to the NGSS Introductory video that provided a clear and concise introduction to the unique aspects of the NGSS which are founded on three dimensions: Disciplinary Core Idea, Science and Engineering Practices, and Crosscutting Concepts. In 
addition to the three dimensions, the letter explained what NGSS Performance Expectations (PEs) were and how PEs combined the three NGSS dimensions. The letter also outlined the three PEs that the field trip program aimed to support.

The email included the Field Trip Program Outline which explained the specific Disciplinary Core Ideas; Science and Engineering Practices; and Crosscutting Concepts that are addressed in the field trip. The Disciplinary Core Idea addressed was Structure and Function; the Crosscutting Concept addressed was Structure and Function; and the two Science and Engineering Practices addressed were Constructing Explanations and Developing and Using Models. The Field Trip Program Outline explained in detail the activities that were going to be facilitated by Nature Guides and outlined the content goal, activity procedure, and the Science and Engineering Practices that were going to be used for each activity.

Finally, the email contained a formative assessment probe that teachers were invited to use as a pre-activity in their K-2 classrooms to set the stage for their students' experiences during the field trip. The probe focused on the concept that all living things are made of parts and that all these parts have specific functions to help an organism survive and reproduce. The purpose of the probe was to help students to 1) recognize that all organisms have parts (focused on external structures), 2) describe how animals use their body parts, 3) identify parts of a plant, and 4) describe basic functions of plant parts (to survive and grow). A copy of the NGSS pre-field trip materials can be found in Appendix A. 


\section{Treatment 2: Field Trip Program with NGSS Aligned Activities}

When teachers, students, and chaperones arrived at Tryon Creek State Park, they were greeted by the field trip coordinator who provided them a brief orientation of the schedule of the day. Students were split up into groups of ten to twelve. Depending on the number of students attending on a certain day, students could be split up into as many as six groups with a maximum of 10 students in each group. Each group was accompanied by a teacher or an adult chaperone and participated in a classroom activity, a hike with NGSS activities, and an overall assessment.

\section{Classroom Activity}

In the classroom, students were engaged in an activity that focused on solving a series of different problems to understand how an organism such as a beaver, frog, or insect uses its body parts to survive in its environment. These activities explored how these organisms used their external body parts to gather, carry, obtain food, or protect itself from danger by developing a deeper understanding of how their body parts (structures) allow them to live (function) successfully in the Tryon forest. Science and Engineering Practices of Constructing Explanations and Developing and Using Models were incorporated.

\section{Trail Activities}

Students also participated in a hike of the Tryon forest. During the hike, nature guides facilitated NGSS-aligned activities. These activities explored how organisms found in the Tryon forest such as woodpeckers, moles, squirrels, birds, seeds, and stinging 
nettle use their body parts (structures) to help them to live and survive (function) in the forest. Science and Engineering Practices of Constructing Explanations and Developing and Using Models were incorporated.

Overall assessment: Create-a-Creature Activity

As an overall assessment towards the end of the field trip, the students engaged in a final assessment called Create-a-Creature where students were to create a brand new creature using materials found along the trail and explain how it finds food, eats food, and protects itself from predators. Science and Engineering Practices of Constructing Explanations and Developing and Using Models were incorporated.

\section{Measurement Instruments: Survey and Interview}

Survey Part 1: Pre/Post Retrospective Survey Methodology

After each field trip, the field trip coordinator emailed each teacher a pre/post retrospective survey to complete. The survey contained a total of 19 statements which consisted of 6 statements regarding awareness and confidence in teaching Disciplinary Core Ideas, 3 questions regarding awareness and confidence in teaching Crosscutting Concepts, 5 statements regarding awareness and confidence in teaching Science and Engineering Practices, and 5 statements regarding awareness and general knowledge about the NGSS. The survey asked teachers to rate their awareness of each statement before the field trip on a 5-point scale from strongly disagree to strongly agree. The survey also asked teachers to rate their awareness of each statement after the field on a 
5-point scale from strongly disagree to strongly agree. A copy of the survey is found in Appendix B.

\section{Pre/Post Retrospective Survey Analysis}

The purpose of this portion of the survey was to learn about the teachers' level of awareness of aspects of the Next Generation Science Standards (NGSS) before attending the field trip and to learn if the teachers' level of awareness increased, decreased, or remained the same after attending the field trip. Four constructs were measured and are as follows: Disciplinary Core Idea, Science and Engineering Practices, Crosscutting Concept, and General Knowledge of the NGSS.

For each of the four constructs, data is organized using a graph and table. The graph shows teachers' awareness and confidence in teaching dimensions of the NGSS prior to treatment. The table shows a comparison of teachers' responses to the statements both before and after treatment. This showed me the extent to which teachers increased their understanding or remained the same after treatment.

\section{Survey Part 2}

The purpose of this portion of the survey was to learn what part of the field trip helped teachers to understand the Disciplinary Core Idea of Structure and Function and during which activities the teachers saw the Science and Engineering Practices carried out. The survey also asked teachers to report which pre-field trip materials they used 
and which NGSS field trip activities they saw throughout the field trip. Questions were in the form of multiple choice and short answer questions.

Interview

All teachers who completed surveys were invited to participate in a semi-structured Interview to gain an in-depth understanding of the teacher's answers to the survey questions. Questions are found in Appendix B. I hoped to learn what part of the field trip helped teachers understand aspects of the NGSS the most. The interviews were conducted by phone and were recorded and transcribed manually.

\section{Results}

\section{Disciplinary Core Idea}

The first construct was the Disciplinary Core Idea (DCI) of Structure and Function. In the survey, there were six statements regarding the $\mathrm{DCl}$. Two of the statements referred to language that is unique to the NGSS. Four of the statements referred to facts that supported the $\mathrm{DCl}$ of Structure and Function.

In the survey, teachers reported how they perceived their awareness and confidence in teaching each of the $\mathrm{DCl}$ statements before the treatment. These responses were graphed to show the teachers' level of awareness and confidence to each statement before the treatment (Figure 1). I found that a majority of the teachers reported a high confidence in teaching facts that supported the DCI but a low awareness of the language used in the NGSS. 
In the survey, teachers also reported their awareness and confidence to each of the statements after the treatment. The responses of each teacher to each statement both before the treatment and after the treatment are compared in Table 1 and show how the teachers perceived their awareness or confidence to each statement before the field trip and how they perceived their awareness or confidence was affected after the treatment. Teachers either reported that their awareness or confidence in teaching a statement increased after treatment (gray boxes) or reported "no change" in their awareness or confidence in teaching a statement (white boxes). I found that only a few teachers reported increases in awareness and confidence per statement after the treatment while a majority reported "no change" in their awareness or confidence in teaching a statement.

Teachers who reported "no change" in their awareness or confidence in teaching a statement retained a high confidence in teaching facts that supported the $\mathrm{DCl}$.

Because of the nature of the five-point scale used on the survey, the data encountered a ceiling effect: teachers who reported a high confidence (rated their confidence level with a 4 or 5) were not able to report if their confidence in teaching these science facts increased after the field trip. Teachers who reported "no change" in their awareness or confidence in teaching a statement also retained a low awareness of the language used in the NGSS. Only a few teachers reported increases in awareness and confidence per statement after the treatment. 


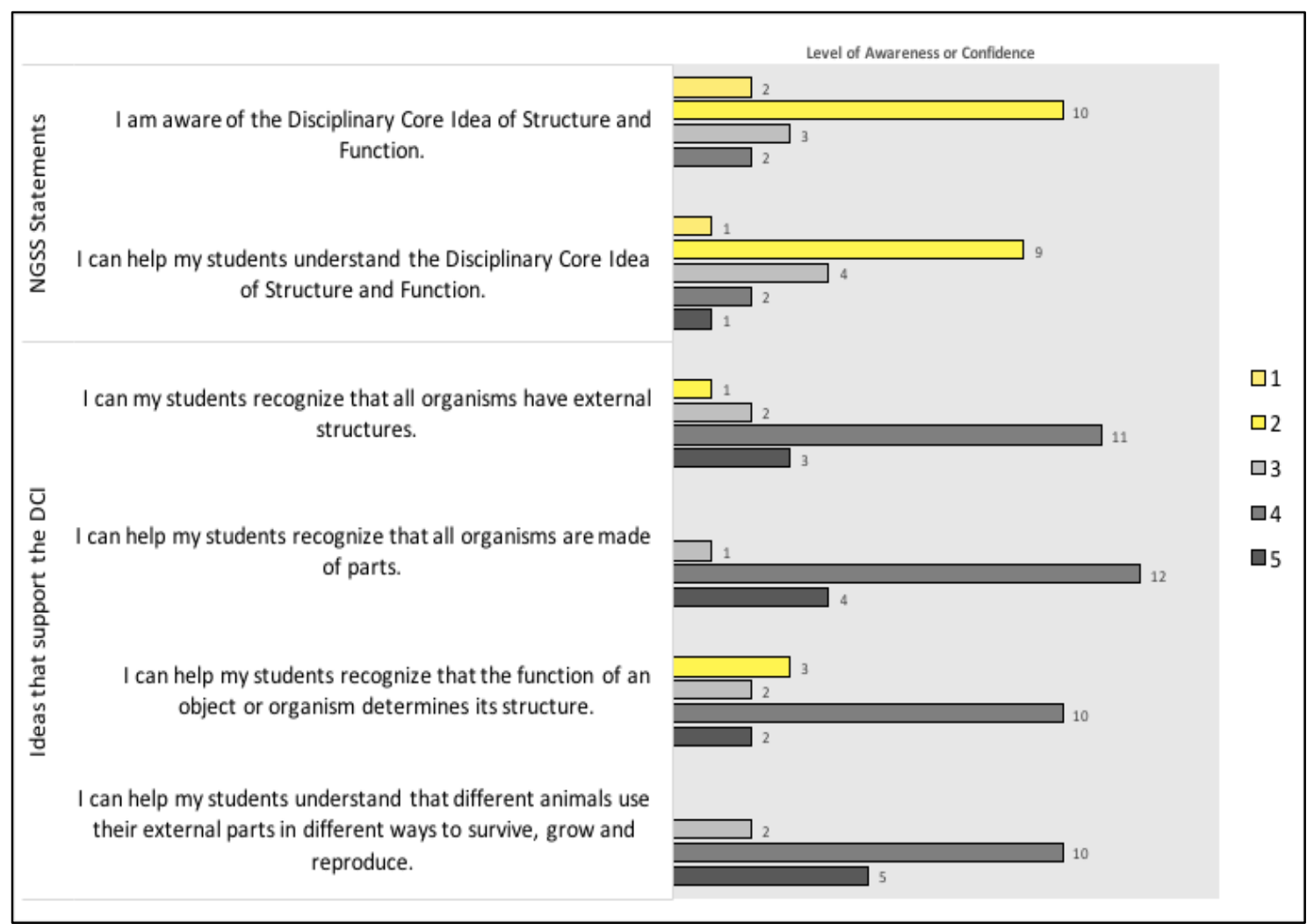

Figure 1. Teacher awareness and confidence in teaching Disciplinary Core Idea prior to treatment $(n=17)$.

Table 1

Teacher Awareness and Confidence in Teaching Disciplinary Core Ideas Before and After Treatment

\begin{tabular}{|c|c|c|c|c|c|c|c|c|c|c|c|c|c|c|c|c|c|c|}
\hline \multirow{2}{*}{\multicolumn{2}{|c|}{ Statements }} & \multicolumn{17}{|c|}{ Teacher } \\
\hline & & 1 & 2 & 3 & 4 & 5 & 6 & 7 & 8 & 9 & 10 & 11 & 12 & 13 & 14 & 15 & 16 & 17 \\
\hline \multirow{2}{*}{$\begin{array}{c}\text { NGSS } \\
\text { Statements }\end{array}$} & $\begin{array}{l}\text { I am aware of the Disciplinary Core Idea of } \\
\text { Structure and Function. }\end{array}$ & $2-2$ & $1-1$ & $4-4$ & $2=2$ & $2-2$ & $1-1$ & $3-3$ & $2-2$ & $2-2$ & $3-3$ & $2-2$ & $2-2$ & $2-4$ & $3-4$ & $2=2$ & $2-3$ & $4-4$ \\
\hline & $\begin{array}{l}\text { I can help my students understand the } \\
\text { Disciplinary Core Idea of Structure and } \\
\text { Function. }\end{array}$ & $2-2$ & $2-2$ & $3-3$ & $3-3$ & $2-2$ & $1-1$ & $3-3$ & $2-2$ & $2-2$ & $3-3$ & $2-4$ & $2-2$ & $2-4$ & $4 \cdot 5$ & $2-2$ & $4-4$ & $5 \cdot 5$ \\
\hline \multirow{4}{*}{$\begin{array}{l}\text { Ideas that } \\
\text { support the } \\
\text { DCl }\end{array}$} & $\begin{array}{l}\text { I can my students recognize that all } \\
\text { organisms have external structures. }\end{array}$ & $4-4$ & 5.5 & $4-4$ & $4 \cdot 4$ & $4-4$ & $4-4$ & $4-4$ & $4-4$ & $4-4$ & $3-3$ & 4.4 & $3-3$ & $2-4$ & $4 \cdot 5$ & 4.5 & $5 \cdot 5$ & $5-5$ \\
\hline & $\begin{array}{l}\text { I can help my students recognize that all } \\
\text { organisms are made of parts. }\end{array}$ & $4-4$ & 5.5 & $4-4$ & $4 \cdot 4$ & $4-4$ & 4.4 & $4-4$ & $4-4$ & $5 \cdot 5$ & $3-3$ & $4-4$ & $4-4$ & $4-4$ & 4.5 & $4 \cdot 5$ & 5.5 & $5 \cdot 5$ \\
\hline & $\begin{array}{l}\text { I can help my students recognize that the } \\
\text { function of an object or organism } \\
\text { determines its structure. }\end{array}$ & $4-4$ & $5-5$ & $4-4$ & $4-4$ & $2-2$ & $5 \cdot 5$ & $4-4$ & $2-2$ & $4-4$ & $3-3$ & $4-4$ & $4-4$ & $2-4$ & $3-4$ & $4-5$ & 4.5 & 4.5 \\
\hline & $\begin{array}{l}\text { I can help my students understand that } \\
\text { different animals use their external parts in } \\
\text { different ways to survive, grow and } \\
\text { reproduce. }\end{array}$ & $4-4$ & $5-5$ & $4-4$ & $4-4$ & $4 \cdot 4$ & $4-4$ & $5-5$ & $4-5$ & $5-5$ & $3-3$ & $4-4$ & $5-5$ & $4-4$ & $3-4$ & $4-5$ & $5-5$ & $4-5$ \\
\hline \multirow{2}{*}{ Note. } & $\begin{array}{l}\text { Gray boxes indicate increase in awareness } \\
\text { or confidence }\end{array}$ & & & & & & & & & & & & & & & & & \\
\hline & $\begin{array}{l}\text { White boxes indicate "no change" in } \\
\text { awareness or confidence }\end{array}$ & & & & & & & & & & & & & & & & & \\
\hline
\end{tabular}




\section{Science and Engineering Practices}

The second construct was the Science and Engineering Practices (SEP). In this program, two SEP were addressed: Constructing Explanations and Developing and Using Models. In the survey, there were five statements regarding the SEP. Two of the statements referred to language that is unique to the NGSS. Four of the statements referred to facts that supported the SEP.

In the survey, teachers reported how they perceived their awareness and confidence in teaching each of the SEP statements before the treatment. These responses were graphed to show the teachers' level of awareness and confidence to each statement before the treatment (Figure 2). I found that a majority of the teachers reported a high confidence in teaching facts that supported the SEP but a low awareness of the language of NGSS.

In the survey, teachers also reported their awareness and confidence to each of the statements after the treatment. The responses of each teacher to each statement both before the treatment and after the treatment are compared in Table 2 and show how the teachers perceived their awareness or confidence was affected after the treatment. Teachers either reported that their awareness or confidence in teaching a statement increased after treatment (gray boxes) or reported "no change" in their awareness or confidence in teaching a statement (white boxes). I found that only a few teachers reported increases in awareness and confidence per statement after the 
treatment while a majority reported "no change" in their awareness or confidence in teaching a statement.

Teachers who reported "no change" in their awareness or confidence in teaching a statement retained a high confidence in teaching facts that supported the SEP.

Because of the nature of the five-point scale used on the survey, the data encountered a ceiling effect: teachers who reported a high confidence (rated their confidence level with a 4 or 5 ) were not able to report if their confidence in teaching these science facts increased after the field trip. Teachers who reported "no change" in their awareness or confidence in teaching a statement also retained a low awareness of the language used in the NGSS. Only a few teachers reported increases in awareness and confidence per statement after the treatment. 


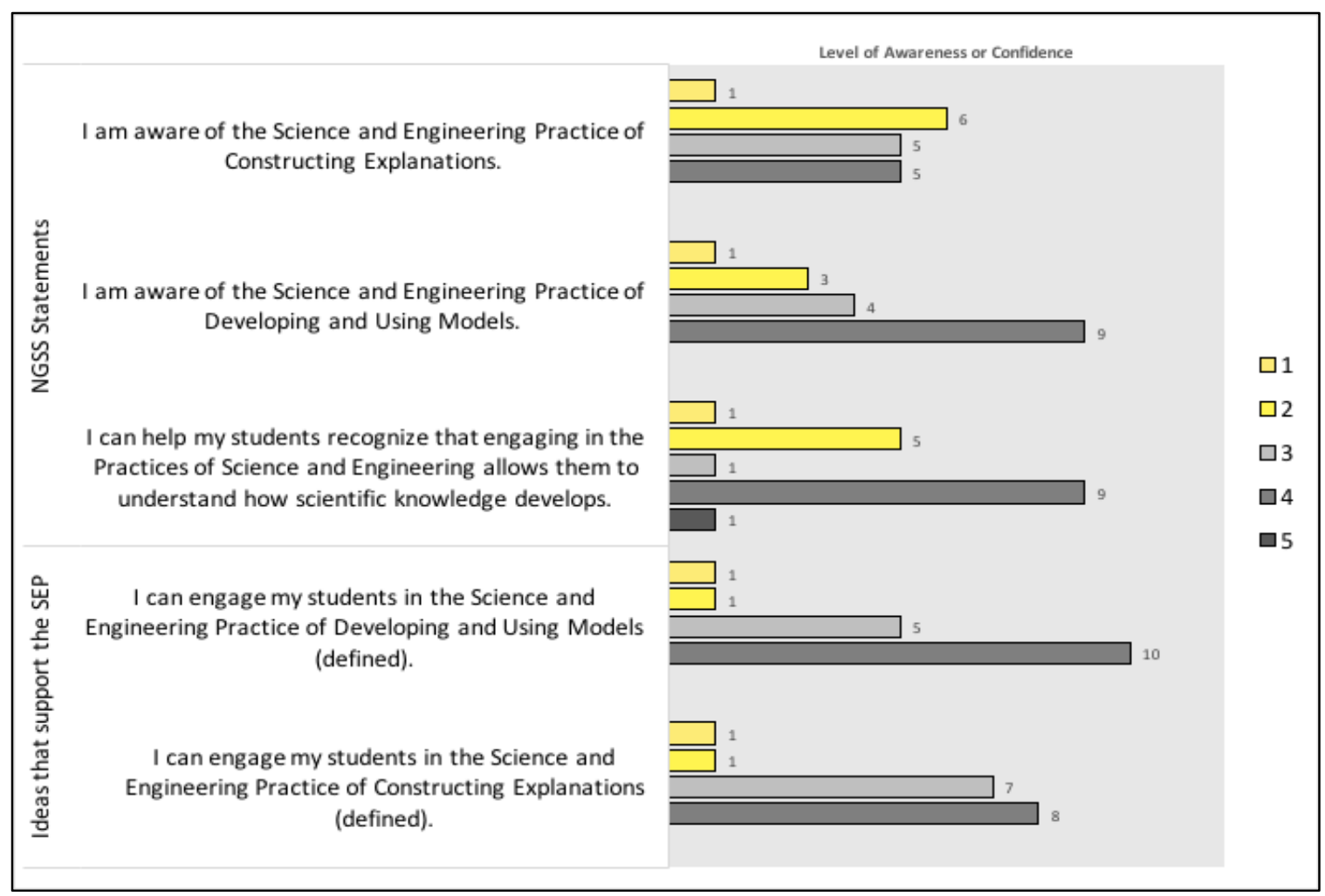

Figure 2. Teacher awareness and confidence in teaching Science and Engineering Practices prior to treatment $(n=17)$.

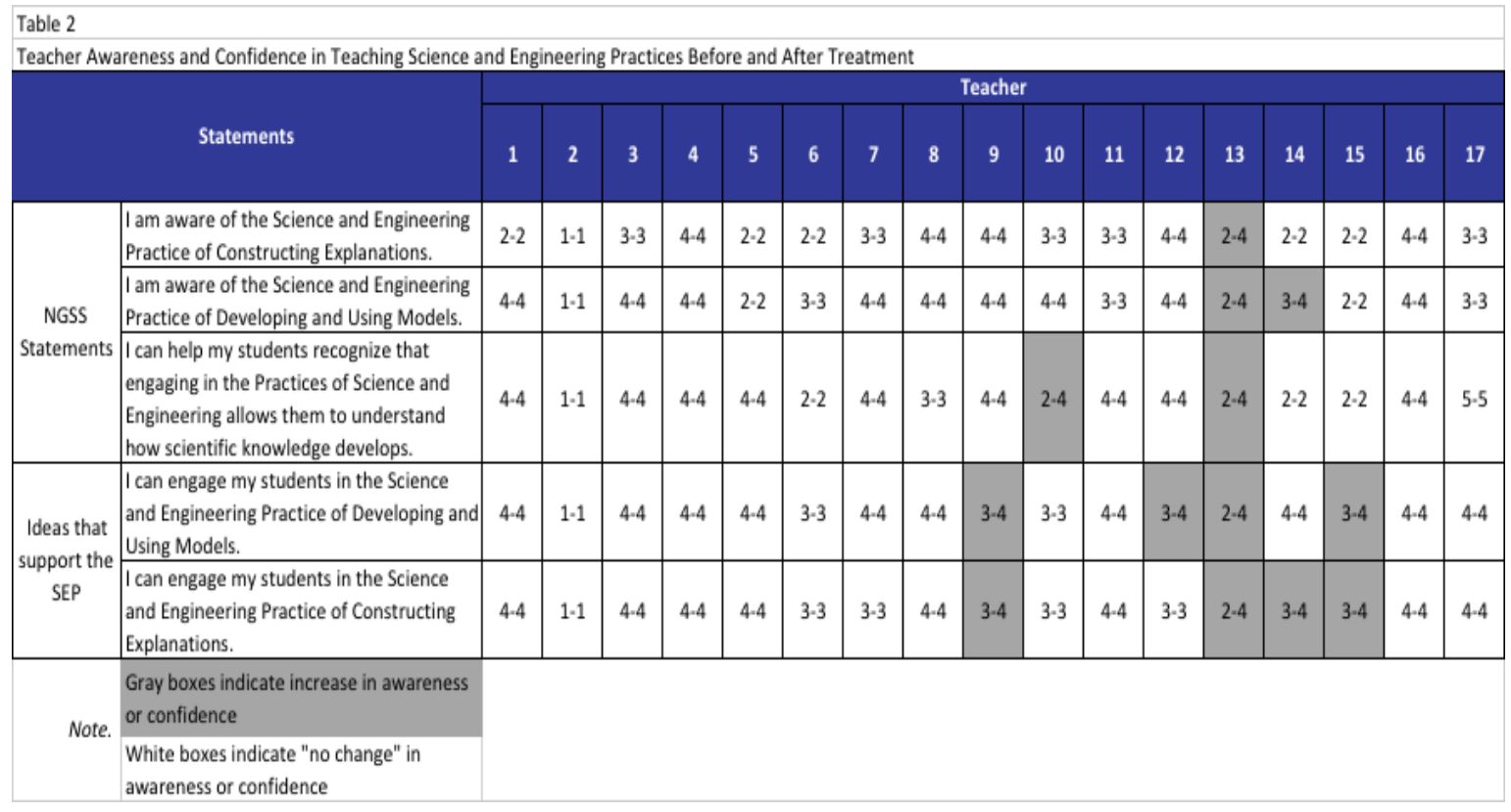




\section{Crosscutting Concepts}

The third construct was the Crosscutting Concept (CCC) of Structure and Function. In the survey, there were three statements regarding the CCC. Two of the statements referred to language that is unique to the NGSS. Four of the statements referred to facts that supported the CCC.

In the survey, teachers reported how they perceived their awareness and confidence in teaching each of the CCC statements before the treatment. These responses were graphed to show the teachers' level of awareness and confidence to each statement before the treatment (Figure 3). I found that a majority of the teachers reported a high confidence in teaching facts that supported the CCC but a low awareness of the language of NGSS.

In the survey, teachers also reported their awareness and confidence to each of the statements after the treatment. The responses of each teacher to each statement both before the treatment and after the treatment are compared in Table 3 and show how the teachers perceived their awareness or confidence to each statement before the field trip and how they perceived their awareness or confidence was affected after the treatment. Teachers either reported that their awareness or confidence in teaching a statement increased after treatment (gray boxes) or reported "no change" in their awareness or confidence in teaching a statement (white boxes). I found that only a few teachers reported increases in awareness and confidence per statement after the 
treatment while a majority reported "no change" in their awareness or confidence in teaching a statement.

Teachers who reported "no change" in their awareness or confidence in teaching a statement retained a high confidence in teaching facts that supported the CCC.

Because of the nature of the five-point scale used on the survey, the data encountered a ceiling effect: teachers who reported a high confidence (rated their confidence level with a 4 or 5 ) were not able to report if their confidence in teaching these science facts increased after the field trip. Teachers who reported "no change" in their awareness or confidence in teaching a statement also retained a low awareness of the language used in the NGSS. Only a few teachers reported increases in awareness and confidence per statement after the treatment. 


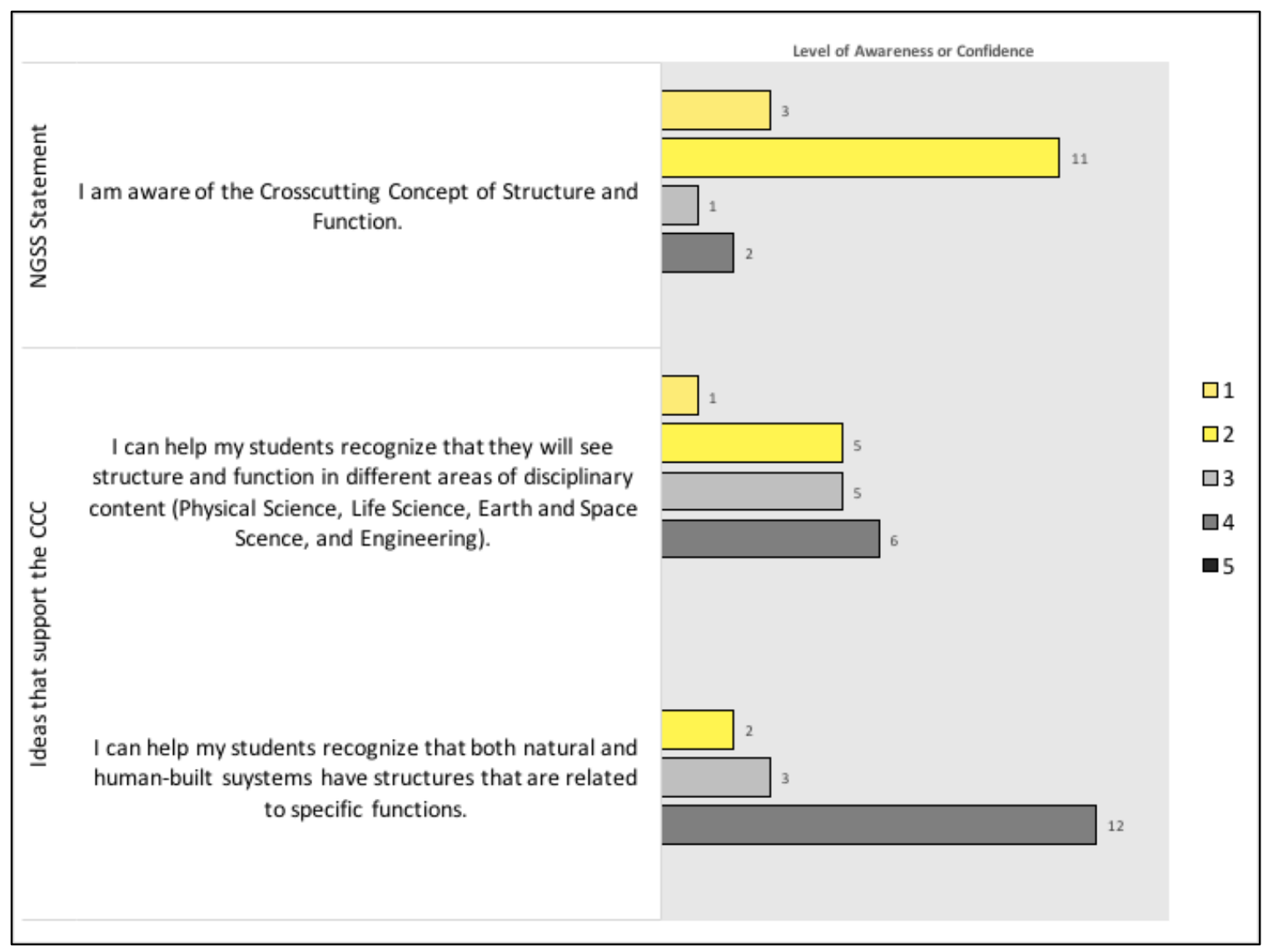

Figure 3. Teacher awareness and confidence in teaching Crosscutting Concepts prior to Treatment $(n=17)$.

Table 3

Teacher Awareness and Confidence in Teaching Crosscutting Concepts Before and After Treatment

\begin{tabular}{|c|c|c|c|c|c|c|c|c|c|c|c|c|c|c|c|c|c|c|}
\hline \multirow{2}{*}{\multicolumn{2}{|c|}{ Statements }} & \multicolumn{17}{|c|}{ Teacher } \\
\hline & & 1 & 2 & 3 & 4 & 5 & 6 & 7 & 8 & 9 & 10 & 11 & 12 & 13 & 14 & 15 & 16 & 17 \\
\hline $\begin{array}{c}\text { NGSS } \\
\text { Statement }\end{array}$ & $\begin{array}{l}\text { I am aware of the Crosscutting Concept of } \\
\text { Structure and Function. }\end{array}$ & $2 \cdot 2$ & $1 \cdot 1$ & $4 \cdot 4$ & 4.4 & 2.2 & $1 \cdot 1$ & $2 \cdot 2$ & $2 \cdot 2$ & $2 \cdot 2$ & 1.1 & $2 \cdot 2$ & $2 \cdot 2$ & $2 \cdot 4$ & $2 \cdot 2$ & $2 \cdot 2$ & $2 \cdot 2$ & $3-3$ \\
\hline \multirow{2}{*}{$\begin{array}{l}\text { Ideas that } \\
\text { support the } \\
\text { CCC }\end{array}$} & $\begin{array}{l}\text { I can help my students recognize that they } \\
\text { will see structure and function in different } \\
\text { areas of disciplinary content (Physical } \\
\text { Science, Life Science, Earth and Space } \\
\text { Scence, and Engineering). }\end{array}$ & 4.4 & 3.3 & 4.4 & 4.4 & 2.2 & 2.2 & 4.4 & 4.4 & 3.3 & $1 \cdot 1$ & 4.4 & 3.3 & $2 \cdot 4$ & 3-4 & 2.2 & $2 \cdot 4$ & 3-4 \\
\hline & $\begin{array}{l}\text { I can help my students recognize that both } \\
\text { natural and human-built suystems have } \\
\text { structures that are related to specific } \\
\text { functions. }\end{array}$ & 4.4 & 4.4 & $4 \cdot 4$ & 4.4 & 2.2 & 4.4 & $4 \cdot 4$ & 4.4 & 4.4 & 3.3 & 4.4 & 4.4 & $2 \cdot 4$ & 4.4 & 3.5 & $4-4$ & $3-4$ \\
\hline \multirow{2}{*}{ Note. } & $\begin{array}{l}\text { Gray boxes indicate increase in awareness } \\
\text { or confidence }\end{array}$ & & & & & & & & & & & & & & & & & \\
\hline & $\begin{array}{l}\text { White boxes indicate "no change" in } \\
\text { awareness or confidence }\end{array}$ & & & & & & & & & & & & & & & & & \\
\hline
\end{tabular}




\section{General NGSS Statements}

The fourth construct was the General NGSS Statements. In the survey, there were five statements regarding general knowledge of the NGSS. Two of the statements referred to language that is unique to the NGSS. Four of the statements referred to ideas that were similar to other standards.

In the survey, teachers reported how they perceived their awareness of each of these general NGSS statements before the treatment. These responses were graphed to show the teachers' level of awareness to each statement before the treatment (Figure 4). I found that a majority of the teachers reported a high awareness of ideas that were similar to other standards and a low awareness of the larger ideas unique to the NGSS that the NGSS has three dimensions of learning.

In the survey, teachers also reported their awareness of each statement after the treatment. The responses of each teacher to each statement both before the treatment and after the treatment are compared in Table 4 and show how the teachers perceived their awareness to each statement before the field trip and how they perceived their awareness was affected after the treatment. Teachers either reported that their awareness of a statement increased after treatment (gray boxes) or reported "no change" in their awareness of a statement (white boxes). I found that only a few teachers reported increases in awareness per statement after the treatment while a majority reported "no change" in their awareness of a statement. 
Teachers who reported "no change" in their awareness of a statement retained a high awareness of the ideas of the NGSS that were similar to other standards. Because of the nature of the five-point scale used on the survey, the data encountered a ceiling effect: teachers who reported a high confidence (rated their awareness level with a 4 or 5) were not able to report if their confidence in teaching these science facts increased after the field trip. Teachers who reported "no change" in their awareness of a statement also retained a low awareness of the language used in the NGSS. Only a few teachers reported increases in awareness per statement after the treatment.

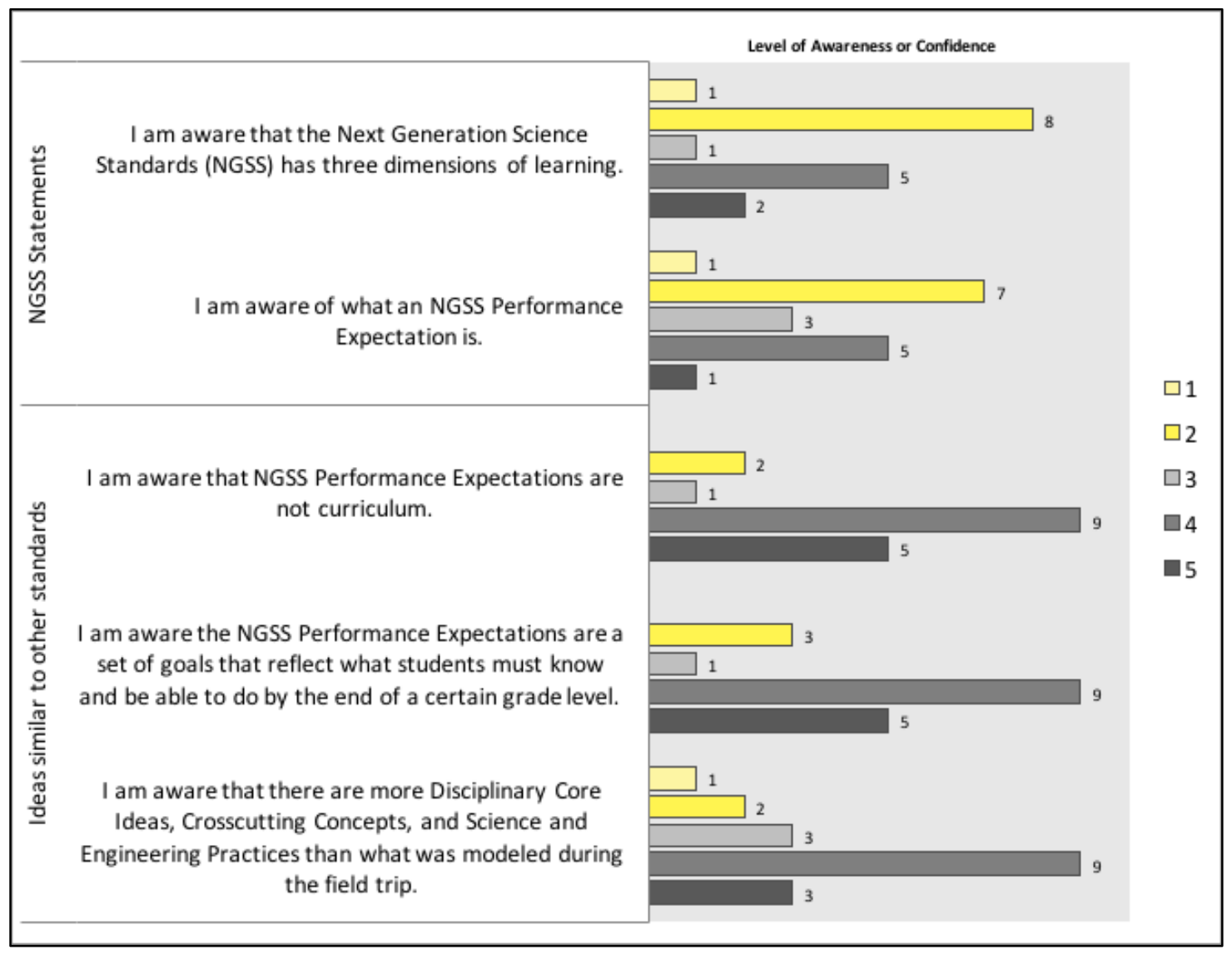

Figure 4. Teacher awareness of general knowledge of NGSS prior to treatment $(n=17)$. 
Table 4

Teacher Awareness of NGSS General Knowledge Before and After Treatment

\begin{tabular}{|c|c|c|c|c|c|c|c|c|c|c|c|c|c|c|c|c|c|c|}
\hline \multirow{2}{*}{\multicolumn{2}{|c|}{ Statements }} & \multicolumn{17}{|c|}{ Teacher } \\
\hline & & 1 & 2 & 3 & 4 & 5 & 6 & 7 & 8 & 9 & 10 & 11 & 12 & 13 & 14 & 15 & 16 & 17 \\
\hline \multirow{2}{*}{$\begin{array}{c}\text { NGSS } \\
\text { Statements }\end{array}$} & $\begin{array}{l}\text { I am aware that the Next Generation } \\
\text { Science Standards (NGSS) has three } \\
\text { dimensions of learning. }\end{array}$ & $4-4$ & $1-1$ & $4-4$ & 3-3 & 4.4 & $2-2$ & 4.4 & $2-2$ & $2-2$ & $2-2$ & $2-2$ & $2-3$ & $4-4$ & 5-5 & $2-2$ & $2-2$ & $5-5$ \\
\hline & $\begin{array}{l}\text { I am aware of what an NGSS Performance } \\
\text { Expectation is. }\end{array}$ & $4-4$ & $1-1$ & $4-4$ & 3-3 & $2-2$ & $2-2$ & $4-4$ & $3-3$ & $2-2$ & $3-3$ & $2-2$ & $2-2$ & $4-4$ & 4.4 & $2-2$ & $2-3$ & $5-5$ \\
\hline \multirow{3}{*}{$\begin{array}{l}\text { Ideas similar } \\
\text { to other } \\
\text { standards }\end{array}$} & $\begin{array}{l}\text { I am aware that NGSS Performance } \\
\text { Expectations are not curriculum. }\end{array}$ & $4 \cdot 4$ & $3-3$ & 4.4 & 4.4 & 4.4 & $5-5$ & 4.4 & $4-4$ & 5-5 & 4.4 & $2-2$ & 4.4 & $4-4$ & 5-5 & $2-2$ & $5-5$ & 5-5 \\
\hline & $\begin{array}{l}\text { I am aware the NGSS Performance } \\
\text { Expectations are a set of goals that reflect } \\
\text { what students must know and be able to } \\
\text { do by the end of a certain grade level. }\end{array}$ & $4-4$ & 3-3 & $4-4$ & $4-4$ & $2-2$ & $5-5$ & $4-4$ & $4-4$ & $4-4$ & $4-4$ & $2-2$ & $5-5$ & $4-4$ & 5-5 & $2-2$ & 4-4 & $5-5$ \\
\hline & $\begin{array}{l}\text { I am aware that there are more } \\
\text { Disciplinary Core Ideas, Crosscutting } \\
\text { Concepts, and Science and Engineering } \\
\text { Practices than what was modeled during } \\
\text { the field trip. }\end{array}$ & $4-4$ & $1-1$ & 4-4 & $4-4$ & $4-4$ & $5-5$ & $4-4$ & $4-4$ & 4-4 & $3-3$ & $2-2$ & $3-3$ & $4-4$ & 5-5 & $2-2$ & $5-5$ & $4-4$ \\
\hline \multirow{2}{*}{ Note. } & $\begin{array}{l}\text { Gray boxes indicate increase in awareness } \\
\text { or confidence }\end{array}$ & & & & & & & & & & & & & & & & & \\
\hline & $\begin{array}{l}\text { White boxes indicate "no change" in } \\
\text { awareness or confidence }\end{array}$ & & & & & & & & & & & & & & & & & \\
\hline
\end{tabular}


For each teacher, the number of statements that he or she reported an increase in awareness to was summed (Figure 5). The data from the graph revealed that 10 of the 17 teachers reported an increase in awareness of the NGSS in at least one statement. This finding also reveals an indication that the program has the potential to help teachers increase their awareness of the NGSS.

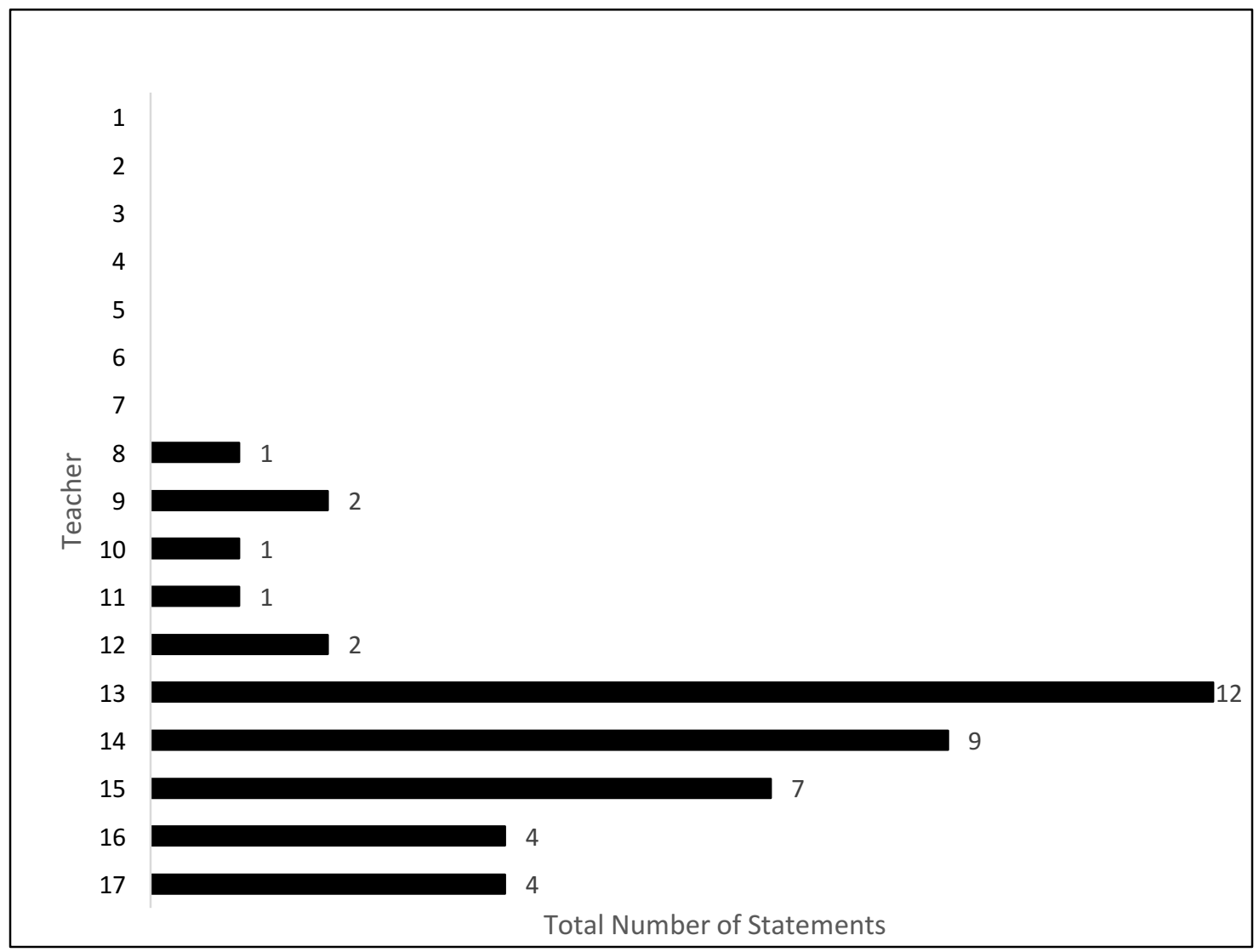

Figure 5. Total number of statements each teacher reported an increase in awareness or confidence after treatment. 


\section{Survey Part 2}

The purpose of this portion of the survey was to learn what part of the field trip helped teachers to understand the Disciplinary Core Idea of Structure and Function and during which activities the teachers saw the Science and Engineering Practices carried out. The questions were either in multiple Choice or short answer form and were coded to allow comparisons.

\section{NGSS pre-field trip materials}

Teachers reported in engaging more than one pre-field trip material (Figure 6). Most teachers engaged in the same number of materials before the field trip.

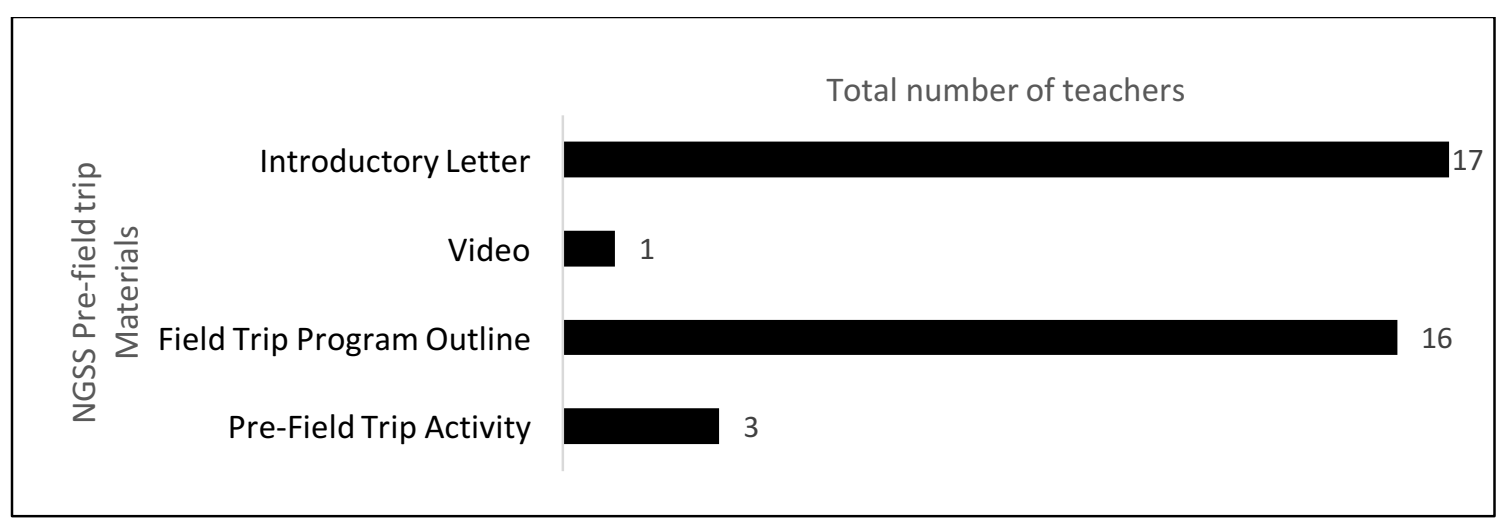

Figure 6. Total number of teachers that reported engaging in each NGSS pre-field trip material $(n=17)$.

\section{NGSS Field Trip Activities}

The survey asked teachers to report which activities they saw throughout the field trip. The number of activities each teacher saw was summed (Figure 7). The results of the graph revealed that teachers did not engage in the same number of activities. Table 5 shows which activity each teacher saw during the field trip. 


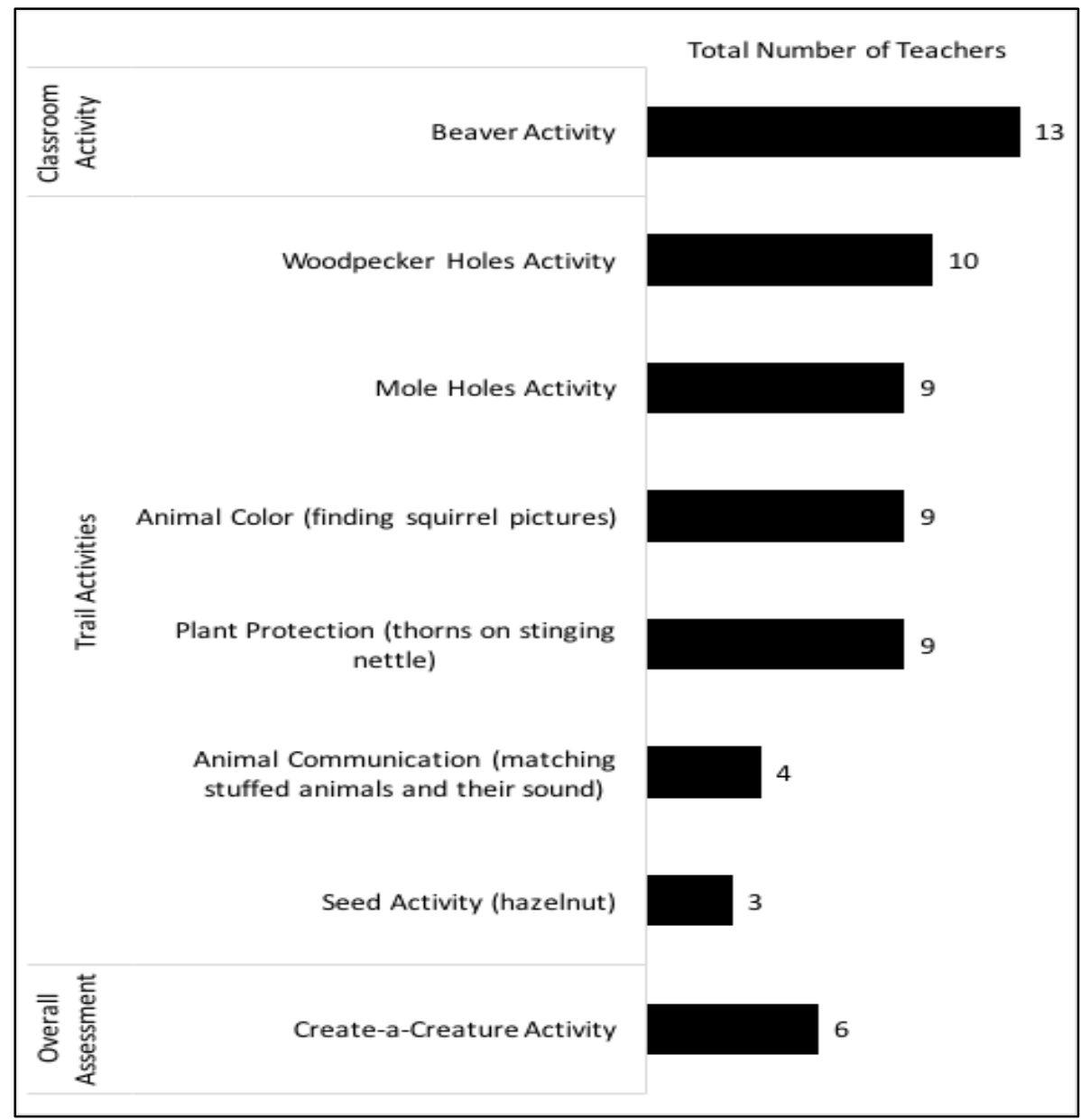

Figure 7. Total number of teachers that reported seeing each NGSS activity on the field trip ( $n=17)$. 
Activities each teacher reported seeing on the field trip

\begin{tabular}{|c|c|c|c|c|c|c|c|c|c|c|c|c|c|c|c|c|c|}
\hline \multirow{2}{*}{ NGSS Field Trip Activities } & \multicolumn{17}{|c|}{ Teacher } \\
\hline & 1 & 2 & 3 & 4 & 5 & 6 & 7 & 8 & 9 & 10 & 11 & 12 & 13 & 14 & 15 & 16 & 17 \\
\hline Beaver Activity & 1 & & 1 & 1 & & 1 & 1 & 1 & 1 & 1 & 1 & & 1 & 1 & 1 & 1 & \\
\hline Woodpecker Holes Activity & 1 & & 1 & 1 & 1 & & & 1 & 1 & & & 1 & 1 & & 1 & & 1 \\
\hline Mole Holes Activity & 1 & 1 & & 1 & & & 1 & 1 & 1 & & & & 1 & & 1 & & 1 \\
\hline Animal Color (finding squirrel pictures) & 1 & & & 1 & 1 & & & & & 1 & & 1 & 1 & 1 & 1 & & 1 \\
\hline $\begin{array}{l}\text { Animal Communication (matching } \\
\text { stuffed animals and their sound) }\end{array}$ & 1 & & & & 1 & & & 1 & & & & & & & 1 & & \\
\hline Seed Activity (hazelnut) & & & & 1 & & & & & & & & & & 1 & & & 1 \\
\hline $\begin{array}{l}\text { Plant Protection (thorns on stinging } \\
\text { nettle) }\end{array}$ & & 1 & & 1 & & & 1 & 1 & 1 & & & 1 & 1 & 1 & & & 1 \\
\hline Create-a-Creature Activity & & & & 1 & & & & & 1 & & & & 1 & 1 & 1 & & 1 \\
\hline
\end{tabular}

\section{Disciplinary Core Idea of Structure and Function}

Teachers reported which part of the field trip helped them understand the Disciplinary

Core Idea of Structure and Function (Figure 8). Each teacher reported one aspect of the field trip.

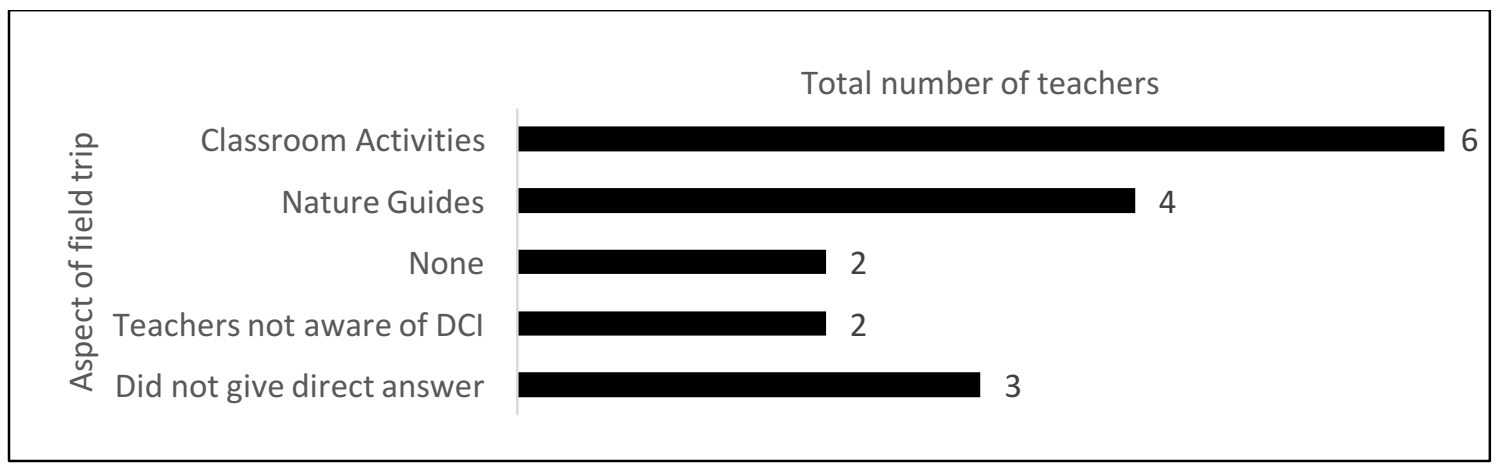

Figure 8. Number of teachers that reported which part of the field trip helped them to understand the Disciplinary Core Idea: Structure and Function $(n=17)$.

\section{Science and Engineering Practice: Constructing Explanations}

Teachers reported that they saw the Science and Engineering Practice of Constructing

Explanations in more than one activity (Figure 9). 


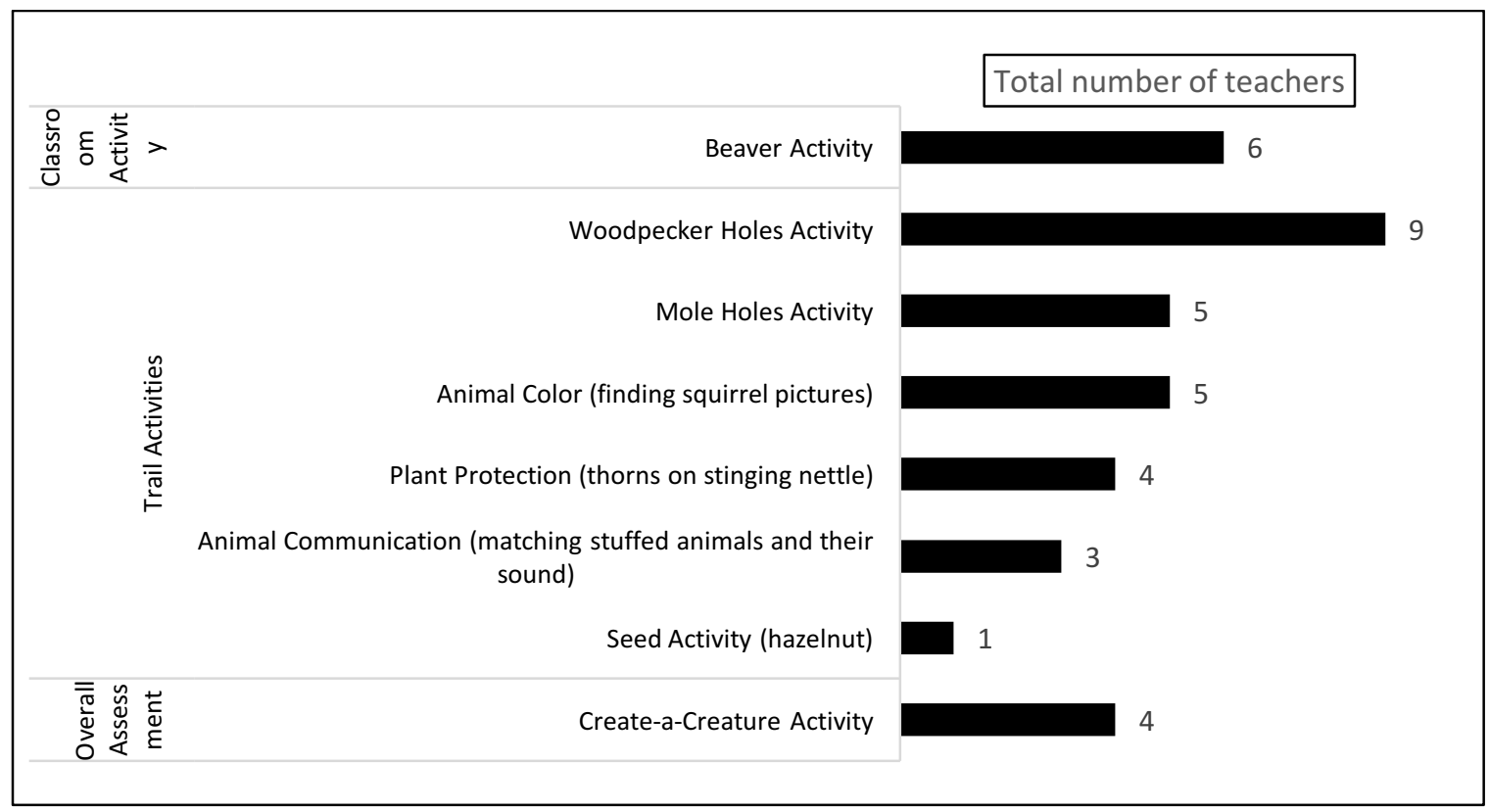

Figure 9. Number of teachers that reported which activities they saw the science and engineering practice of constructing explanations $(n=17)$.

\section{Science and Engineering Practice: Developing and Using Models}

Teachers reported that they saw the Science and Engineering Practice of Developing and Using Models in more than one activity (Figure 10). 


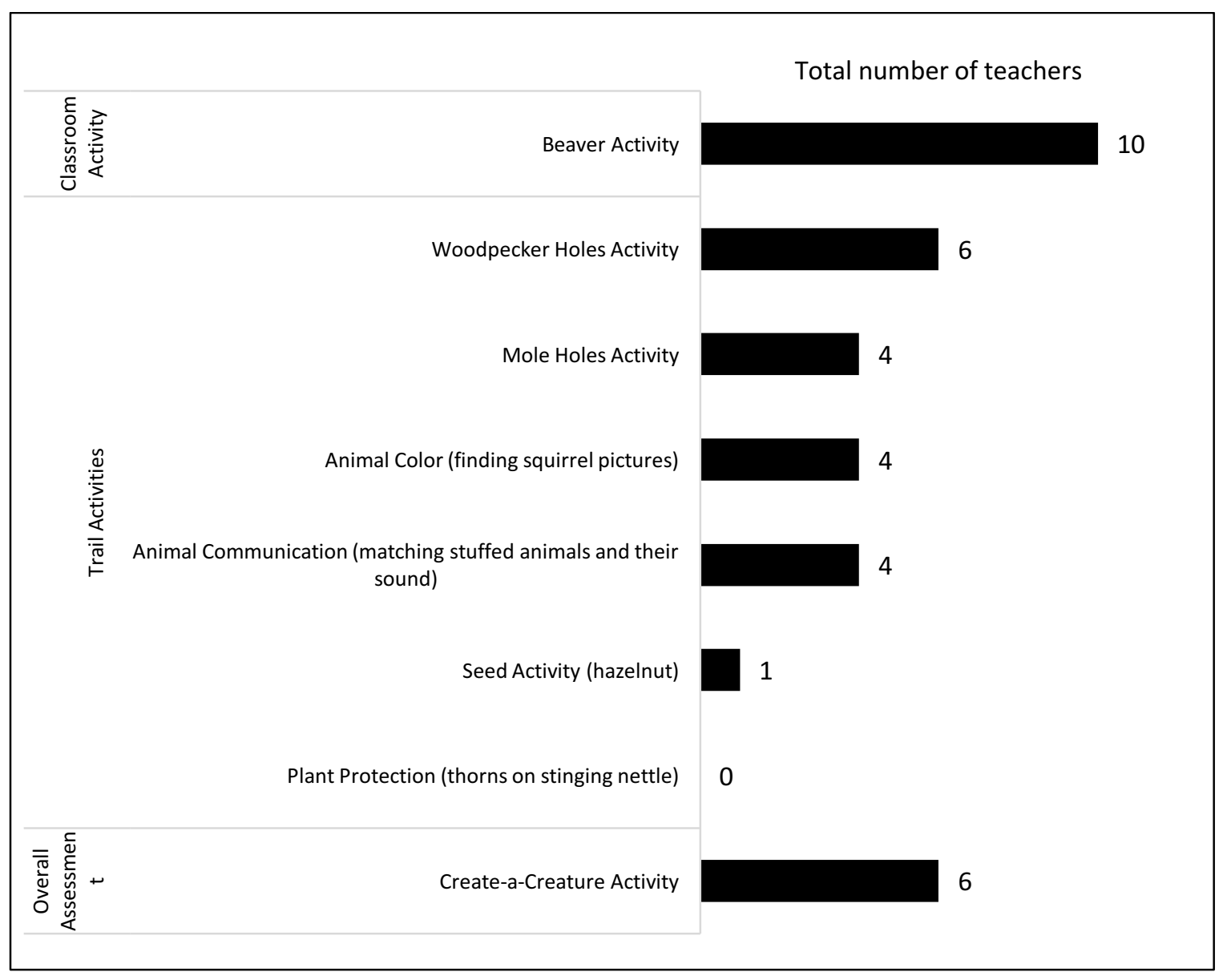

Figure 10. Number of teachers that reported which activities they saw the Science and Engineering Practice: Developing and Using Models ( $n=17)$.

\section{Interviews}

The purpose of the interviews was to gain an in-depth understanding of the teacher's answers to the survey questions. A total of 4 teachers were interviewed. The full transcript of the interviews can be found in Appendix C.

Interview Question 1: What materials did you receive in advance? Did you receive and engage in any material regarding the Next Generation Science Standards before the field trip? 
Among the interviewees, two teachers reported that they engaged in the prefield trip material regarding the NGSS while two teachers reported that they did not engage in the materials. Teacher 13 and 17 reported that they engaged in the materials and found them beneficial. One of them said, "We did that 'is it made of parts' probe assessment...I felt like my kids did really really well understanding...that these different animals and human were made of parts...except when it came to the snake and the seed and the worm - that was bit trickier. But I really enjoyed doing that assessment because I felt like it was a good set up to then go on the field trip, you know. So I really enjoyed that..." The other teacher said, "I did [notice information about the NGSS in particular]. I did like the structure of having...the information ahead of time of what you guys were going to be talking about and being able to do some basic conversation about it and then see it and then we got into deeper conversation when we...got back to school." Teacher 6 and 7 reported that they did not engage in the materials and gave insight as to why they did not engage in any of the NGSS pre-field trip materials. Both teachers cited that they received a lot of information and emails before attending the field trip and admitted that they did not read all of it. One teacher said, "Before we went, a couple of weeks before, I received information about what the field trip would be about. And it had learning activities that I could do with my classroom. And it was actually just a ton of information that I received. And, l'll be honest, I only went through part of it..." The other teacher said, "...my problem this year was that I didn't have a lot of time to read through things. My attitude was that I just had to get the kids ready...so I 
think I might have gotten more emails that I didn't read. But anything that was pertaining to what [the field trip coordinator] needed me to do I did. I don't recall [receiving anything regarding the NGSS]...maybe there was but I don't remember anything." From both responses, it seemed that teachers may have been overwhelmed with the materials they received before the field trip and prioritized some emails over others. As a result, they were not aware of the NGSS being implemented into the field trip.

From the survey data, I found that all four interviewees reported that they engaged in the pre-field trip materials. However, during the interviews, I found that two of the teachers' responses differed from what they reported on the survey as they reported that they did not engage in the pre-materials. The survey asked teachers to report which pre-field trip materials they engaged in (I.e. "introductory letter", "field trip program outline"). However, the survey did not specifically ask if teachers read or engaged in NGSS-related materials. Consequently, teachers may have reported on the survey that they had read the introductory letter, for example, but may have been referring to an introductory letter sent at the very beginning of their scheduling process and not the NGSS-related introductory letter that was sent one week before their scheduled field trip. As a result, the data from that portion of the survey is not reliable and it cannot be inferred what helped teachers to increase their awareness of the NGSS from this portion of the survey. Fortunately, the interviews provided valuable insight as to what pre-field trip materials teachers engaged in and helped them to increase their awareness and 
confidence in teaching the NGSS dimensions and were a more reliable source.

The key lesson learned from this question was that not all teachers engaged in the NGSS pre-field trip materials even if they had reported that they did on the survey. I learned that the reason teachers did not engage in the materials was because they simply overlooked the email sent to them or did not have enough time to read all the emails that were sent to them before the field trip. For teachers that engaged in the NGSS pre-field trip materials, I learned that the teachers found the NGSS pre-activity and the Field Trip Program Outline useful in preparing their students for the field trip. Interview Question 2: Can you tell me where you saw or heard the Disciplinary Core Idea of Structure and Function at any point during the field trip?

The most common response among the interviewees was that they saw the $\mathrm{DCl}$ of Structure and Function during the Beaver Activity. Three of the four teachers gave this response. Teacher 6 said, "We talked about, um, like a beaver's tail, and a beaver's claws, and its teeth...I think they were moles that were making all those holes. But we talked about, you know, how their claws worked and helped them in the hole and, you know, how fast they could dig the dirt, you know, and all that type of things." Teacher 7 said, "I think in the classroom it was going on because the Tyron Creek volunteer was talking to the kids about the beaver. And she was talking to them explicitly about the body parts of the beaver and how the body parts have adapted in a way for the beaver to survive. So there was a lot of conversation about the beaver's tail and how it flaps. And how it flaps, it's telling its children that there's danger." Teacher 13 said, "We talked 
about it in the beaver activity. In the beaver activity, they talked about the different parts and what it was used for - the claws, the tail, the fur. We talked about the teeth and what the functions of that were...the beaver activity - that was a big part of it."

All interviewees also made mention to seeing the DCl of Structure and Function being seen during various activities conducted on the trail: different beaks on different birds, what they're used for and what would this bird eat; the structure of a stinging nettle and its function; woodpecker's skull and tongue and how it functions.

Teacher 13 added that it was in the NGSS pre-field trip materials that she saw the DCl of Structure and Function and said, "I felt like the pre-assessment helped me and I've been away of it before but never in those terms [...]. so it was nice to have those terms there and even using those terms with my students I think is important...I felt like this was a really good background foundation for me to continue next year when we study animal adaptations and when we study plants just thinking about the form and the function of the different parts. And that ties right into our adaptation unit. So it's just nice to add those words into my sort of awareness and to also use those terms in different ways with my kids with our adaptions unit that we're going to do next year." Just like in the survey, among the various activities conducted during the field trip, the Beaver Activity in the classroom was what most of the teachers mentioned that they saw the DCI. From the interviews, I learned that the teachers found the classroom Beaver Activity to be the activity that best supported the $\mathrm{DCl}$ of Structure and Function. Unlike the survey where teachers only mentioned field trip activities, one teacher added 
in the interview that she saw this concept in the pre-field trip materials. This is an indication that both pre-field trip materials and the field trip activities were useful in learning about the $\mathrm{DCl}$ of Structure and Function.

Interview Question 3: The Science and Engineering Practice of Constructing Explanations involves using information from observations to construct an evidence based account for natural phenomena. Do you recall if there was a point in the field trip where your students were asked to construct their own explanations based on evidence they found?

Common to all four interviewees responses was that each cited specific examples of how the nature guide explicitly asked students to explain a phenomena using evidence during various points in the field trip. Teacher 6 said, "The seed dispersal definitely. Because they [the students] were so into that...he [the nature guide] would ask them questions: "How could this have gotten from point A to point B?" And they came up with a million ways: 'A bird could take it, an animal could take it, it could stick on your fur,' you know, 'the wind,' things like that." Teacher 7 said, "Yes. Definitely. There was a lot of investigative kind of work that went on where they were asked [by the nature guide], 'Well what do you think about that? or "What would you do if you were an animal?" or "Why do you think the plant has done that?" The guy that was our guide, definitely, I think he was a high school teacher, so he definitely asked them some questions... kind of hypothesizing a little bit..." Teacher 13 said, "...when we were doing the trail, I remember the guide, one of my kids would point out and notice a banana slug 
or notice a cone or notice something - a hole - and she would ask questions, for sure: 'Why do you think that's that way?' and 'What do you think that's for?' And so I totally remember she asking lots of questions and having the kids respond, absolutely, I couldn't tell you the exact questions or details but I do remember that exchange for sure." Teacher 13 also added, "I think when they did the create their own animal they definitely had to explain, for sure. That was really a clear and obvious one." Teacher 17 said, "I think during when they built their own animals [Create-a-Creature Activity]. I think that was the only time. [The nature guide asked] 'Why did you give it those wings?' and 'What would that do for it?' and I think those were the only ones [activities] that they [students] really kind of gave [opportunities for] their explanations. I mean they gave thoughts on things and asked questions. But I think that was the only time they were really giving their like [explanations]." From these responses, I learned that nature guides played an instrumental role in helping teachers to see the SEP of Constructing Explanations during the field trip. From Teacher 13 and 17, I learned that the Create-a-Creature Activity is promising to be most effective for allowing the students to engage in the SEP of Constructing Explanations.

The survey question asked teachers to report which activities they saw the SEP of Constructing Explanations during the field trip. However, when asked during the interviews, the teachers talked about the nature guides. The interview allowed for teachers to provide more in depth responses as to what aspect of the field trip helped them to understand the SEP of Constructing Explanations than what data from the 
survey could provide.

Interview Question 4: Developing and Using Models in the K-2 level involves creating physical replica to represent phenomena and distinguishing between a model and the actual object the model represents. Do you recall if there was a point in the field trip where your students used a model to represent relationships? Or learned to distinguish between a model and the actual object the model represents?

Two teachers cited specific examples from activities during the field trip. Teacher 6 's response reflected her understanding of Developing and Using Models and cited examples of how tools were used as representations of a certain animal. She also cited the use of an animal pelt to represent a real animal and it is likely that she didn't have a full understanding of what a model is and is not. Teacher 6 said, “...his [nature guide's] dead animals [teacher referring to animal pelts] were good models...he would just show us, you know, how little moles' paws kind of looked like a tiny fork. And then he had a fork and he dug through the dirt with that. And then the woodpeckers' beak, you know... he put it into a hole and showed them, you know, how deep it could actually go into a hole. And what would be inside the hole, things like that. In the classroom, we did the whole game, both of the games had the models... tools that we used that were not the true, you know, it wasn't a true claw but it was... I think one was like a spatula [representing] like a beaver's tail or something like that. And how fast it could go through water. And what it could do, things like that, yeah." Teacher 17 mentioned that 
the Overall Assessment: Create-a-Creature activity involved Developing and Using Models but did not cite anything specific.

Teacher 7 could not cite an example and said, "I don't remember seeing anything like that. I think we might have had conversion about the beak but I don't think so and maybe the other guides may have talked about that more. I was only on one group, so the other guides might have definitely talked about it." Even if Teacher 7 did not see Developing and Using Models on the field trip, she stated that its importance and said, “...that's really a good idea. That should definitely be added....kids need hands - on. They need to touch things and they need to be able to actually experience that wonder of "oh, so that's why that bird has such a long beak or " that's why that bird..."

Teacher 13 cited specific examples related to how the nature guide "modeled" or gave instructions for students in the proper use of tools demonstrating a lack of understanding of modeling in NGSS terms. She said, "I think the beaver activity was definitely in line with the modeling because you know the guide was there and she would show an example of how to use the tongs or the spoon about making noise. She had that as a model for the kids to think about how they would use these different tools to communicate or to solve a problem or to build something. And so she used that modeling for sure. On the trail, I can't remember, I know when they had to build their own animal she started by doing something just to show. I think she grabbed one or two things nearby and just used that as an example because that was a pretty intuitive activity and the kids just got right to it, she didn't need to do much modeling there." 
On the surveys, teachers marked which activities they thought exhibited the SEP of Developing and Using Models. However, their responses from their interview showed that they might not have had an accurate understanding of Developing and Using Models in the NGSS. There wasn't a single strong activity for developing and using models that teachers referenced for this particular SEP. Perhaps they may not have seen the activities on the trail or teachers did not fully understand the definition of modeling in the NGSS sense.

Interview Question 5: Structure and Function is a concept found in all areas of science in both natural and human-built systems. Can you tell me where you saw or heard or saw this idea at any point during the field trip?

None of the four teachers could cite an example of the CCC of Structure and Function. Teacher 6 said, “Um, I don't - remember I didn't read them all [referring to the NGSS pre-field trip materials]. It was probably in there. Yeah. He did talk about the human built systems. I can't really think of what it was. I'm trying to think. I know that there probably were. And we did talk about like our hands and, um, you know, we looked at our own human hands and [discussed], 'What are they good for?' Things like that, compared to animals' hands, and you know, 'Are they webbed? Are they this? Tips of our fingers super sharp?' No. You know, things like that. But I can't think of anything. No I just can't think of anything. I'm sure we discussed some things. He had a lot of knowledge." Teacher 7 said, "I don't think so...I think it was probably brought up. I think it was brought up but I don't think it was brought up in those terms. I think it was 
simplified so that kids would understand it. But it was definitely addressed...it's almost like I need to understand that a little bit more myself." Teacher 17 said, "We didn't really touch on that. I'm trying to think. I'm trying to recall, and I mean, I think a little of that applies in the classroom. I mean talking about the differences in our hands so I think when I think of the CCC, I think the most we saw of that was in the classroom when we were doing those. I felt like all of the guides in there were kind of using that, 'how is that different from how you are and how is that...' I felt that there was more of that there."

Teacher 13, attempted a guess and said, "Well I felt like the engineering part was when we created our own animal on the trail part because that's when they were designing and building their own animals and I had quite a few kids building 2 or 3 different animals or had a team of kids building one big animal and then talking about the different parts. I felt that that was engineering, wouldn't you say that's correct?"

The teachers' inability to respond was expected. The only time the CCC was mentioned was in the NGSS pre-field trip materials. It was not explicitly mentioned during the field trip. From the interview, it is apparent that more work needs to be done to address the CCC during the field trip. On another hand, this data also reveals that addressing the CCC during a two-hour field trip is a challenge, and a two-hour field trip might not be enough time to address the CCC. 


\section{Discussion}

Given that there are very few face to face opportunities for teachers to receive professional development training regarding the NGSS, there is a great need for teachers to be trained to effectively teach the three areas of the NGSS (J. Rumage, personal communication, September 26, 2016). Two goals of the NGSS are to connect science to the real world and to focus on deeper understanding of NGSS content and science practices (NRC, 2012). Previous studies have shown that teachers are in need of professional development opportunities that focus on conceptual understanding of science topics and are aligned with state standards (Chval et al., 2007). Non-formal education programs have played a role in teacher professional development (Melber and Cox - Peterson, 2005; Holliday et al., 2014; Sackes et al., 2011; Anderson et al., 2006).

Time and location are the largest constraining factors that affect teacher participation in professional development trainings. To address this constraint, Tryon Creek State Park offered a NGSS professional development training opportunity for teachers that was integrated within a field trip that they took their students on. Before the field trip, teachers were introduced to the NGSS through a set of NGSS pre-field trip materials, which informed them about the NGSS and how aspects of it would be integrated into their students' field trip. Teachers accompanied their students on a twohour long field trip at Tryon Creek State Park where teachers observed nature guides model NGSS-aligned activities for the students. 
My study aimed to answer: In what ways can an informal science education program affect K-2 teachers' awareness of the Next Generation Science Standards? The following section outlines the study's major findings: 1) a small number of teachers reported an increase in awareness of the Disciplinary Core Idea, Crosscutting Concept, Science and Engineering Practices, and General Knowledge of the Next Generation Science Standards after the field trip, 2) a majority of the teachers reported no change in awareness of the Disciplinary Core Idea, Crosscutting Concept, Science and Engineering Practices, and General Knowledge of the Next Generation Science Standards statements after the field trip.

\section{Prior to treatment}

Teachers reported their level of awareness and confidence in teaching NGSS

dimensions prior to treatment. A majority of the teachers reported that they had a high understanding of the ideas that supported the NGSS. The science facts addressed during the field trip were not necessarily complex to grasp (i.e. All animals are made of parts, animals use their different body parts to survive, reproduce, and grow). A majority of the teachers also reported that they had a low awareness of the terms/language of the NGSS. The language of the NGSS is new and challenging.

\section{After treatment}

Teachers who Reported "No Change" in Awareness and Confidence

A majority of the teachers reported "no change" in confidence in teaching NGSS Dimensions after the treatment. In each of the four constructs - DCl, SEP, CCC, and 
General NGSS Knowledge Statements - a trend was found where a majority of the teachers retained a high confidence in teaching the science facts that support each dimension of the NGSS. Because of the nature of the five-point scale used on the survey, the data encountered a ceiling effect: teachers who reported a high confidence (rated their confidence level with a 4 or 5) were not able to report if their confidence in teaching these science facts increased after the field trip.

A majority of the teachers reported "no change" in awareness of the NGSS dimensions after the treatment. In each of the four constructs - DCI, SEP, CCC, and General NGSS Knowledge Statements - a trend was found where a majority of the teachers retained a low awareness of terms/language used in the NGSS (Table 1, 2, 3, 4). The language of the NGSS is challenging (i.e. Disciplinary Core Idea of Structure and Function, Science and Engineering Practice of Developing and Using Models) and may be one of the challenges that teachers will face when implementing the NGSS. This finding leaves room for the Field Trip Program to work on to increase understanding the NGSS. Teachers who Reported an Increase in Awareness and Confidence

A few teachers reported an increase in awareness and confidence in teaching NGSS Dimensions after the treatment. In each of the four constructs - DCI, SEP, CCC, and General NGSS Knowledge - a trend was found where a few teachers reported increases in awareness and confidence in teaching NGSS dimensions (Table 1, 2, 3, 4). There were two aspects of the treatment that helped these teachers to report an increase in awareness of the NGSS: NGSS Pre-Field Trip Materials and the NGSS Field Trip Activities. 


\section{NGSS Pre-Field Trip Materials}

In the survey data, I found that teachers reported that they engaged in almost exactly the same number of pre-field trip materials (Figure 6). However, during the interviews, I found that some teachers' responses differed from what they reported on the survey. When asked if they engaged in the NGSS pre-field trip materials, two of the teachers explained that they did not receive or engage in any of them or were not aware of these materials before the field trip even if they had reported that they did on the survey; two of the teachers explained that they did engage in the NGSS pre-field trip material before attending the field trip.

The survey asked teachers to report which pre-field trip materials they engaged in (I.e. "introductory letter", field trip program outline"). However, the survey did not specifically ask if teachers read or engaged in NGSS-related materials. Consequently, teachers may have reported on the survey that had read the introductory letter, for example, but may have been referring to an introductory letter sent at the very beginning of their scheduling process and not the NGSS-related introductory letter that was sent one week before their scheduled field trip. As a result, the data from that portion of the survey is not reliable and it cannot be inferred what helped teachers to increase their awareness of the NGSS from this portion of the survey. Fortunately, the interviews provided valuable insight as to what pre-field trip materials teachers engaged in and helped them to increase their awareness and confidence in teaching the NGSS dimensions. 
Teacher 6 and 7 did not engage in the NGSS Pre-field trip material; teacher 13 and 17 engaged in the NGSS Pre-field trip material. For each of the four teachers interviewed, I looked at how many statements each of them reported an increase in awareness and confidence in teaching NGSS dimensions (Figure 5). A correlation existed between the teachers who engaged in NGSS pre-field trip materials and the number of statements that each teacher improved on: teachers who engaged in the NGSS pre-field trip material showed an increase in awareness of the NGSS statements while teachers who did not engage in the NGSS pre-field trip materials did not show an increase in awareness of the NGSS after the field trip. From the data obtained from the interviews, there is evidence to show that teachers who engaged in materials before the field trip showed increase in awareness or confidence in teaching the statements while teachers who did not engage in materials before the field trip did not show any increase in awareness or confidence.

The findings are weak, but promising. The number of teachers that reported engaging in the NGSS pre-field trip material is not large enough to make a statistically significant claim that the pre-field trip materials contributed to increasing teachers' awareness and confidence in teaching NGSS dimensions. Although only four teachers showed a correlation between engaging in pre-field trip material and increases in awareness to the DCI, SEP, and CCC, and General NGSS statements, these findings suggest that reading the materials beforehand may be the single most important factor 
in helping a teacher increase their awareness and confidence in teaching the NGSS dimensions.

\section{NGSS Field Trip Activities}

I also wanted to see if there was any evidence to show if any NGSS field trip activities helped teachers to increase their awareness and confidence in teaching NGSS dimensions. In looking at all 17 teachers, there was no correlation between the number of NGSS field trip activities each teacher saw and the number of increases in awareness or confidence each teacher reported (Table 5). I zoomed in and looked at teachers who showed the most significant amount of changes compared to the other teachers.

Teacher 13,14, and 15 reported an increase in awareness and confidence in five or more NGSS statements after the field trip (Figure 5). I looked at the activities that each of these three teachers reported seeing during the field trip and found that those teachers saw the same three activities on the field trip: Beaver classroom activity, the Animal Color Activity, and the Create-a-Creature Activity (Table 5).

A correlation existed between certain NGSS field trip activities these three teachers saw and the number of statements each teacher reported an increase in awareness: the teachers who saw Beaver classroom activity, the Animal Color Activity, and the Create-a-Creature Activity reported an increase in awareness and confidence in seven or more NGSS statements after the field trip. Teacher 4 also reported seeing all three activities, but she reported that she already had a high understanding of the NGSS concepts before the field trip and because of the nature of the five-point scale survey, 
was not able to report if her awareness and confidence increased after the field trip. The rest of the 13 teachers did not see all three activities and reported four or less increases in awareness or confidence. There is evidence to show that teachers who engaged in these three activities showed increases in awareness to seven or more statements while teachers who did not engage in these three activities on the field trip showed four or less increases in awareness.

The findings are weak, but promising. The number of teachers that engaged in these three activities is not large enough to make a claim that these activities contributed to increasing teachers' awareness and confidence in teaching the NGSS dimensions. However, these three activities - the beaver activity in the classroom, the animal color activity, and the create-a-creature activity-may be the most effective parts of the field trip in helping teachers increase their awareness and confidence in teaching the NGSS dimensions.

\section{Limitations}

\section{NGSS Pre-Field Trip Materials}

The survey asked teachers to report which materials they read or engaged in before attending the field trip: i.e. "introductory letter, field trip program outline." However, the survey did not specifically ask if teachers read or engaged in NGSS-related materials. This could have caused some confusion when teachers reported whether or not they read or engaged in the materials before the field trip. For example, teachers may have reported that they read or engaged in the initial introductory letter at the beginning 
when they signed up for the field trip months in advance and not the NGSS-related introductory letter that was sent one week before their scheduled field trip. As a result, the data from that portion of the survey is not reliable and it cannot be inferred what helped teachers to increase their awareness of the NGSS from this portion of the survey.

The interviews provided more insight into what helped teachers increase their awareness of the NGSS. From the interviews, it was found that some teachers did not engage in the NGSS pre-field trip material. It is possible that the majority of teachers who reported no change in awareness to the NGSS statements did not engage in the NGSS pre-field trip materials. Teachers may not have read the pre-materials due to several reasons: 1 ) The timing of the materials being sent. Teachers were only sent the NGSS materials one week before their scheduled field trip. One week may not be much time to read the materials given the busy schedule of the teacher. 2) The amount of materials sent to teachers before the field trip. Before being sent the NGSS materials, teachers were already receiving a ton of other information from the field trip coordinator regarding logistics, etc. Adding the NGSS materials may have been too overwhelming for teachers and could have been easily overlooked. 3) Teachers not being aware of the professional development opportunity when they signed up for the field trip. When teachers initially signed up to attend the field trip program, they did not sign up to learn about the NGSS. It was only one week before their field trip that they were informed of the implementation of the NGSS to their field trip. As a result, teachers may not have been aware there was a professional development opportunity 
involved regarding the NGSS. Although the interviews provided more insight into teachers who engaged in the pre-materials, only four interviews were conducted and that is not large enough to tell us that the pre-materials were indeed an effective means. 4) Distribution of pre-field trip materials. For each class that scheduled a field trip, there could have been as many as six sections in the grade that attended with six different teachers. When scheduling the field trip, one teacher was decided to be "point person" to receive all emails from the field trip coordinator and send all emails to the rest of the teachers. It is possible that "point person" teachers did not forward the NGSS emails to the rest of the teachers resulting in teachers not receiving the NGSS materials or responding to the survey.

\section{NGSS Field Trip Activities}

From the data, there was evidence that teachers did not see the same NGSS activities during the field trip. Teachers may not have seen the same activities due to the nature guide each teacher had that day. The nature guides varied in experience day to day. Nature guides may not have done all the same activities. Most of the NGSS aligned activities were new additions to the field trip program and nature guides may not have had sufficient training to be comfortable teaching according to the NGSS practices. As a result, teachers may not have seen the NGSS activities during the field trip.

\section{Recommendations}

From the results we see that the majority of teachers had a high confidence in teaching the science facts that support the NGSS dimensions but had a low awareness of 
the language used in the NGSS. We also see that, with a few exceptions, teachers retained this response after the field trip. From this data, it can be inferred that awareness of the language of the NGSS is what teachers most need to improve on. To best focus the professional development opportunity on what teachers actually need, I recommend intentionality of NGSS pre-field trip materials and intentionality of training of nature guides regarding the NGSS.

\section{Intentionality of NGSS Pre-Field Trip Materials}

From the very beginning when scheduling a field trip experience with Tryon Creek State Park, the professional development component should be made explicit to teachers. Teachers should be informed that in addition to providing an educational field trip experience for their students, the field trip could serve as a form of professional development for them to learn about the NGSS. Teachers should also be sent these NGSS pre-materials as early as when they sign up for the field trip so that they can make time to look over the material before attending the field trip. The survey should ask if teachers noticed NGSS materials in particular: NGSS introductory letter, field trip program outline with NGSS components." Intentionality of Training of Nature Guides regarding the NGSS

From the results, we see that the majority of teachers did not see the same activities during the field trip. It is possible that nature guides did not conduct the NGSS aligned activities. Because most of the NGSS aligned activities were recent additions to Tryon Creek's field trip program, nature guides may not have had sufficient training to 
be comfortable in teaching according to the NGSS practices. Nature guides need to be further trained regarding the NGSS in order to be prepared to conduct the NGSS aligned activities. Findings showed that if nature guides conducted activities such as the Beaver Activity, Animal Color Activity (finding squirrel cutouts), and Create-a-Creature Activity, teachers increase their awareness and confidence in teaching the NGSS dimensions.

\section{Conclusion}

My study aimed to answer: In what ways can an informal science education program affect K-2 teachers' awareness and confidence in teaching the Next Generation Science Standards? Findings of this study suggest that engaging in the NGSS pre-field trip materials before attending the field trip may contribute to an increase in awareness and confidence in teaching the NGSS. Findings also suggest that observing certain NGSS activities during the field trip may contribute to an increase in awareness and confidence in teaching the NGSS. The findings of the study are weak, but promising. The number of teachers that reported increases in awareness is not large enough to make a claim on the effectiveness of the program. Although only a few teachers reported increases in awareness to the DCI, SEP, and CCC, and General NGSS statements, these findings reveal an indication that the field trip program has potential to support teacher professional development regarding the NGSS and to help teachers increase their awareness and confidence in teaching the NGSS dimensions. 


\section{References}

Anderson, D., Kisiel, J., \& Storksdieck, M. (2006). Understanding Teachers' Perspectives on Field Trips: Discovering Common Ground in Three Countries. Curator: The Museum Journal, 49(3), 365-386. doi:10.1111/j.2151-6952.2006.tb00229.x

Chval, K., Abell, S., Pareja, E., Musikul, K., \& Ritzka, G. (2007). Science and Mathematics Teachers' Experiences, Needs, and Expectations Regarding Professional Development. Eurasia Journal of Mathematics, Science \& Technology Education, 4(1), 31-43. Retrieved February 15, 2016.

Holliday, G. M., Lederman, J. S., \& Lederman, N. G. (2014). "Wow! Look at That!": Discourse as a Means to Improve Teachers' Science Content Learning in Informal Science Institutions. Journal of Science Teacher Education, 25(8), 935952. Retrieved February 15, 2016.

Kisiel, J. (2005). Understanding elementary teacher motivations for science fieldtrips. Science Education, 89(6), 936-955. doi:10.1002/sce.20085

Melber, L. M., \& Cox-Petersen, A. M. (2005). Teacher Professional Development and Informal Learning Environments: Investigating Partnerships and Possibilities. Journal of Science Teacher Education, 16(2), 103-120. Retrieved February 15, 2016.

National Research Council (2012). A Framework for K-12 Science Education: Practices, Crosscutting Concepts, and Core Ideas. Washington, DC: The National Academies Press.

NGSS Lead States (2013). Next Generation Science Standards: For states, by states. Washington, D.C.: National Academies Press.

Oregon Department of Education (2016). Oregon STEM Website 2016 Retrieved from https://sites.google.com/a/oregonlearning.org/oregon-stemupdate/home/educator-resources-i/osucourse-forestastheclassroom)

Saçkes, M., Trundle, K., \& Krissek, L. (2015). The Impact of a Summer Institute on Inservice Early Childhood Teachers' Knowledge of Earth and Space Science Concepts. Science Educator, 20(1), 35-65. Retrieved February 15, 2016.

Zhang, M., Parker, J., Koehler, M. J., \& Eberhardt, J. (2015). Understanding Inservice Science Teachers' Needs for Professional Development. Journal of Science Teacher Education, 26(5), 471-496. Retrieved February 15, 2016 


\section{Adaptable Animals}

Season

Any
Grades

K- 2
Time

2 hours

\section{Essential Question} How do the structures of organisms enable life's functions?

\section{Disciplinary Core Idea}

LS1.A: Structure and Function All organisms have external parts. Different animals use their body parts in different ways to see, hear, grasp objects, protect themselves, move from place to place, and seek, find, and take in food, water, and air. Plants also have different parts (roots, stems, leaves, flowers, \& fruits) that help them survive, grow, and produce more plants.

\section{Crosscutting Concept}

Structure and Function

K-2 The shape and stability of structures of natural and designed objects are related to their function(s).

\section{Science and}

\section{Engineering Practices}

Developing and Using Models

K-2

Distinguish between a model and the actual object the model represents. Use a model to represent amounts, relationships, relative scale (bigger, smaller) and/or patterns in the natural world. Constructing Explanations K-2

\section{Teacher Notes}

- The Next Generation Science Standards (NGSS) is the most recently developed set of standards that will guide $\mathrm{K}-12$ schools in the United States in the areas of science.

- The NGSS is based upon a Framework for $\mathrm{K}-12$ Science Education, which is built on three dimensions: Disciplinary Core Ideas, Crosscutting Concepts, and Science and Engineering Practices. An Essential Question guides each Disciplinary Core Idea.

- As shown on the left hand column, the Adaptable Animals program will focus on teaching the Disciplinary Core Idea_and Crosscutting Concept of Structure and Function; and the Science and Engineering Practices of Developing and Using Models and Constructing Explanations.

- Included are a list of activities your students will engage in that aim to integrate the three dimensions of the NGSS.

\section{All materials will be provided during your field trip}

\begin{tabular}{cl}
\hline \multicolumn{2}{|l}{ Materials } \\
$\circ$ & Various pelts (mole) \\
$\circ$ & White squirrel cutouts \\
$\circ$ & Various skulls (woodpecker) \\
$\circ$ & Beaver Investigation Kits \\
$\circ$ & Screwdrivers \\
$\circ$ & Spoons \\
$\circ$ & Stuffed animals: squirrel, owl, bird \\
$\circ$ & Bags of 10 hazelnuts (1 per student) \\
$\circ$ & Picture of germinating hazelnut \\
$\circ$ & Maple seeds
\end{tabular}




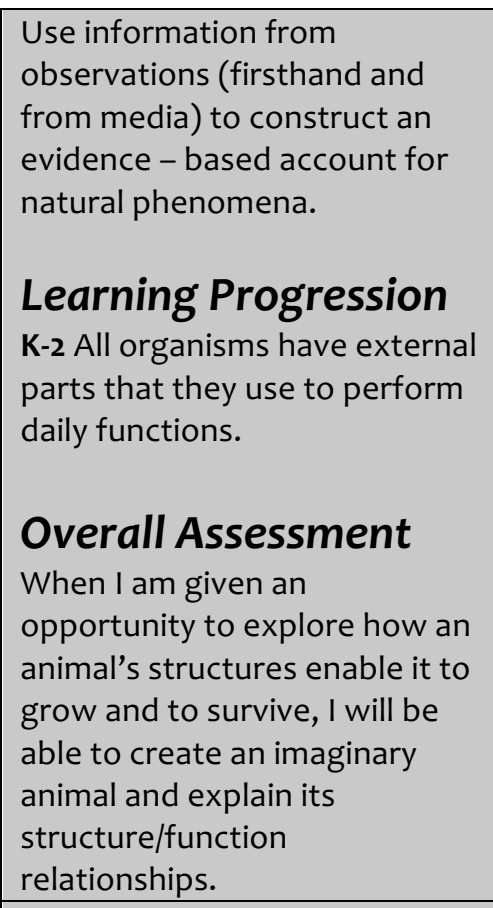

\section{Overall Assessment}

When I am given an

opportunity to explore how an

animal's structures enable it to

grow and to survive, I will be

able to create an imaginary

animal and explain its

structure/function

relationships.

Tryon Classroom Activity - 20 minutes

\section{Beaver Activity}

\section{Guiding Question}

How do an animal's structures help it to survive in its environment?

\section{Content Goal}

Animals have external parts that help them survive (find and eat food, protect themselves from predators, and change their environment) in their specific habitats.

\section{Activity Procedure}

1. Students divide into groups with Nature Guides, each around a carpet in the classroom.

2. Students work together to solve different problems using an array of man-made objects:

a. Carry and stack small logs

i. Spoons

ii. Cloth gloves with no thumbs

iii. Work gloves

b. Strip wood off a stick

i. Nail file

ii. Fork

iii. Flathead screwdriver

c. Make a loud noise to warn others of danger

\section{Science and Engineering Practices}

Developing and using models

- Distinguish between a model and the actual object the model represents.

- Use a model to represent amounts, relationships, relative scale (bigger, smaller) and/or patterns in the natural world.

Constructing explanations

- Make observations (firsthand or from media) to construct an evidence-based account for natural phenomena. 


\begin{tabular}{|c|c|}
\hline $\begin{array}{l}\text { i. Cloth } \\
\text { ii. Flyswatter } \\
\text { iii. Sticks } \\
\text { 3. Students then make observations of } \\
\text { taxidermied examples of beavers to identify } \\
\text { the structure that best corresponds with the } \\
\text { object they chose in step } 2 \text {. } \\
\text { a. Students are asked to support their } \\
\text { arguments with evidence, if } \\
\text { necessary } \\
\text { b. Guide concludes by explaining the } \\
\text { true function of each structure (if } \\
\text { necessary). }\end{array}$ & \\
\hline $\begin{array}{l}\text { Materials } \\
\text { Beaver kit }\end{array}$ & \\
\hline \multicolumn{2}{|c|}{ Trail Activities (not in any order) - 1 hour, 20 minutes } \\
\hline $\begin{array}{l}\text { Guiding Question } \\
\text { What body part does an animal use to make } \\
\text { holes? }\end{array}$ & $\begin{array}{l}\text { Content Goal } \\
\text { Animals use different parts of their body to } \\
\text { make holes. }\end{array}$ \\
\hline $\begin{array}{l}\text { Activity Procedure } \\
\text { 1. Students make observations about the holes } \\
\text { on trees and the holes in the ground, paying } \\
\text { attention to the differences in size, shape, } \\
\text { and location of the holes. } \\
\text { 2. Students are guided to a dead log and open } \\
\text { ground space or preferably a mole mound } \\
\text { 3. Students are given the following tools: spoon } \\
\text { and screwdriver. } \\
\text { 4. Students are asked to re-create the holes } \\
\text { they observed on both the log and the } \\
\text { ground trying both the spoon and } \\
\text { screwdriver on each surface. } \\
\text { a. Which tool allows an animal to make } \\
\text { holes on a tree? } \\
\text { b. Which tool allows an animal to make } \\
\text { holes in the ground? } \\
\text { 5. Students are shown mole pelt and the picture } \\
\text { of a woodpecker beak. } \\
\text { a. Which body part does an animal use } \\
\text { to make holes on a tree? Why do you } \\
\text { think that? }\end{array}$ & $\begin{array}{l}\text { Science and Engineering Practices } \\
\text { Developing and using models } \\
\text { Distinguish between a model and the } \\
\text { actual object the model represents. } \\
\text { Use a model to represent amounts, } \\
\text { relationships, relative scale (bigger, } \\
\text { smaller) and/or patterns in the natural } \\
\text { world. } \\
\text { Constructing explanations } \\
\text { Make observations (firsthand or from } \\
\text { media) to construct an evidence-based } \\
\text { account for natural phenomena. }\end{array}$ \\
\hline
\end{tabular}




\begin{tabular}{|c|c|}
\hline $\begin{array}{l}\text { to make holes in the ground? Why do } \\
\text { you think that? } \\
\text { 6. Answer: Woodpeckers use their beak to } \\
\text { make holes on a tree because it is almost } \\
\text { shaped like a screwdriver and functions to dig } \\
\text { a hole in hard wood. } \\
\text { 7. Moles use their limbs to make holes in the } \\
\text { ground because their limbs are almost shaped } \\
\text { like spoons which function to scoop dirt. }\end{array}$ & \\
\hline $\begin{array}{l}\text { Materials } \\
\text { Screwdrivers, spoons, picture of woodpecker } \\
\text { beak and mole pelt }\end{array}$ & \\
\hline $\begin{array}{l}\text { Guiding Question } \\
\text { Does an animal's color affect its ability to } \\
\text { survive? }\end{array}$ & $\begin{array}{l}\text { Content Goal } \\
\text { Animals have colors that help them survive. } \\
\text { Camouflage helps them either hide from } \\
\text { predators or sneak up on prey. }\end{array}$ \\
\hline $\begin{array}{l}\text { Activity Procedure } \\
\text { 1. Students are given a limited time to collect } \\
\text { hidden animal cutouts of various colors. } \\
\text { a. Which colors were easiest to find? } \\
\text { Hardest? } \\
\text { b. How do colors and patterns benefit } \\
\text { animals? } \\
\text { c. Why is it helpful to be hard to see as a } \\
\text { prey animal? As a predator? } \\
\text { d. What other ways to animals protect } \\
\text { themselves from predators or work to } \\
\text { find prey? }\end{array}$ & $\begin{array}{l}\text { Science and Engineering Practices } \\
\text { Developing and using models } \\
\text { Distinguish between a model and the } \\
\text { actual object the model represents. } \\
\text { Use a model to represent amounts, } \\
\text { relationships, relative scale (bigger, } \\
\text { smaller) and/or patterns in the natural } \\
\text { world. } \\
\text { Constructing explanations } \\
\text { Make observations (firsthand or from } \\
\text { media) to construct an evidence- } \\
\text { based account for natural } \\
\text { phenomena. }\end{array}$ \\
\hline $\begin{array}{l}\text { Materials } \\
\text { White squirrel cutouts (10) }\end{array}$ & \\
\hline $\begin{array}{l}\text { Guiding Question } \\
\text { What body parts do animals use to hear? How } \\
\text { do they use that sound? }\end{array}$ & $\begin{array}{l}\text { Content Goal } \\
\text { Animals use their body parts to hear which } \\
\text { allows them to gather information about their } \\
\text { surroundings to support survival. }\end{array}$ \\
\hline $\begin{array}{l}\text { Activity Procedure } \\
\text { 1. Students are split into pairs. } \\
\text { 2. Each pair is given a different stuffed animal } \\
\text { that produces a sound: squirrel, owl, bird, or }\end{array}$ & $\begin{array}{l}\text { Science and Engineering Practices } \\
\text { Developing and using models } \\
\text { Distinguish between a model and the } \\
\text { actual object the model represents. }\end{array}$ \\
\hline
\end{tabular}




\begin{tabular}{|c|c|}
\hline $\begin{array}{l}\text { 3. Each pair is asked to remember which animal } \\
\text { sound they have. (Might also want to give } \\
\text { them an animal "necklace" to help them } \\
\text { remember) } \\
\text { 4. In each pair, one student's job will be to hold } \\
\text { the stuffed animal and hide. The other } \\
\text { student's job will be to close their eyes. } \\
\text { 5. When the nature guide says "Start!" the } \\
\text { student hiding will play the sound while the } \\
\text { other student will seek their partner based on } \\
\text { their animal sound. } \\
\text { 6. Students will be asked: } \\
\text { a. What body part did you use to find } \\
\text { your animal? } \\
\text { b. How does your animal hear? } \\
\text { c. How do you think your animal uses } \\
\text { sound to help it survive? }\end{array}$ & $\begin{array}{l}\text { Use a model to represent amounts, } \\
\text { relationships, relative scale (bigger, } \\
\text { smaller) and/or patterns in the natural } \\
\text { world. } \\
\text { Constructing explanations } \\
\text { Make observations (firsthand or from } \\
\text { media) to construct an evidence- } \\
\text { based account for natural } \\
\text { phenomena. }\end{array}$ \\
\hline $\begin{array}{l}\text { Materials } \\
\text { Stuffed animals: squirrel, owl, bird }\end{array}$ & \\
\hline $\begin{array}{l}\text { Guiding Question } \\
\text { What structures do seeds have to help them } \\
\text { survive? }\end{array}$ & $\begin{array}{l}\text { Content Goal } \\
\text { Plants have structures that help them survive. } \\
\text { Seeds specifically have structures that assist with } \\
\text { dispersal. }\end{array}$ \\
\hline $\begin{array}{l}\text { Activity Procedure } \\
\text { 1. Students are given } 10 \text { hazel nuts and asked to } \\
\text { pretend they are squirrels. They can pretend } \\
\text { to eat the nuts or hide them. "Eaten" nuts } \\
\text { are given back to the Nature Guide. They can } \\
\text { actually go into the forest and hide the nuts } \\
\text { they do not "eat". } \\
\text { 2. Later during the hike, return to the location } \\
\text { where the nuts were hidden. Ask the } \\
\text { students to go find the nuts they hid. Count } \\
\text { how many nuts were not found. } \\
\text { a. What do you think will happen to the } \\
\text { nuts you did not find? } \\
\text { 3. Look carefully at the nuts: } \\
\text { a. What part of the nut helps to protect } \\
\text { the baby tree? } \\
\text { b. Why do you think it helps the tree to } \\
\text { have squirrels move the nuts around? } \\
\text { 4. Give students maple "helicopter" seeds to } \\
\text { throw in the air. } \\
\text { a. How are these seeds moving around }\end{array}$ & $\begin{array}{l}\text { Science and Engineering Practices } \\
\text { Constructing explanations } \\
\circ \text { Make observations (firsthand or from } \\
\text { media) to construct an evidence-based } \\
\text { account for natural phenomena. }\end{array}$ \\
\hline
\end{tabular}




\begin{tabular}{|c|c|}
\hline $\begin{array}{l}\text { compared to the hazel nuts? } \\
\text { b. Can you thing of other ways you have } \\
\text { seen seeds move? } \\
\text { c. What did those structures look like? }\end{array}$ & \\
\hline $\begin{array}{l}\text { Materials } \\
\text { Bags of } 10 \text { hazelnuts ( } 1 \text { per students), picture of } \\
\text { germinating hazelnut, maple seeds }\end{array}$ & \\
\hline \multicolumn{2}{|c|}{ Plant Protection } \\
\hline $\begin{array}{l}\text { Guiding Question } \\
\text { What parts do plants use to protect } \\
\text { themselves? How does this help them survive? }\end{array}$ & $\begin{array}{l}\text { Content Goal } \\
\quad \text { Plants have parts for protection }\end{array}$ \\
\hline $\begin{array}{l}\text { Activity Procedure } \\
\text { 1. Students are led to a group of plants that } \\
\text { have an obvious defense mechanism. } \\
\text { a. Which part of the plant would you not } \\
\text { want to touch? Why? } \\
\text { b. Do you think this is useful for a plant? } \\
\text { Why? }\end{array}$ & $\begin{array}{l}\text { Science and Engineering Practices } \\
\text { Constructing explanations } \\
\circ \quad \text { Make observations (firsthand or from } \\
\text { media) to construct an evidence-based } \\
\text { account for natural phenomena. }\end{array}$ \\
\hline Materials & \\
\hline \multicolumn{2}{|c|}{ Overall Assessment } \\
\hline \multicolumn{2}{|c|}{ Create-A-Creature Activity } \\
\hline $\begin{array}{l}\text { Guiding Question } \\
\text { If there was a new animal living in Tryon Creek, } \\
\text { what does it need to look like to survive? }\end{array}$ & $\begin{array}{l}\text { Content Goal - Overall Assessment } \\
\text { When given an opportunity to explore how } \\
\text { an animal's structures enable it to grow and } \\
\text { to survive, students will be able to create an } \\
\text { imaginary animal and explain its } \\
\text { structure/function relationships. }\end{array}$ \\
\hline
\end{tabular}




\section{Activity Procedure}

1. Break students into groups of 2 or 3.

2. Introduction: Tell students that they are going to create a brand-new creature using materials they find along the trail.

a. How will your creature find food?

b. How will your creature eat food?

c. Protect itself from predators?

3. Give students 10 minutes to create the creature.

4. Gallery Walk: Gather students together and move as a group to each of the creatures. Have the students explain how their creature's structures support the functions of finding food, eating food, and protecting itself.

5. Use the checklist to assess how well they were able to apply the concept of structure and function to their creature.

\section{Science and Engineering Practices}

Developing and using models

- Distinguish between a model and the actual object the model represents.

- Compare models to identify common features and differences.

- Develop and/or use a model to represent amounts, relationships, relative scale (bigger, smaller) and/or patterns in the natural world.

Constructing explanations

- Make observations (firsthand or from media) to construct an evidence-based account for natural phenomena

\section{Wrap-Up - Shelter - 10 minutes}

* What are some structures or body parts that help organisms survive or meet their needs here at Tryon?

* What structures or body parts do you have that help you survive or meet your needs?

- Species have different characteristics that help them meet their needs in their environments.

- Structures or body parts allow organisms to meet their needs and help organisms to survive.

- Without structures or body parts, you or other organisms wouldn't be able to live successfully. 


\section{Formative ASSESSMent • Promoting learning through ossessment}

\section{Is It Made of Parts?: Scaffolding a Formative Assessment Probe}

\section{By Page Keeley}

A 11 living things, from a tiny, single-celled bacterium to an enormous blue whale, are made of parts. These parts have specific functions that help organisms carry out their life processes. Parts are made up of even smaller parts all organisms are made up of cells, which contain smaller parts within the cell, which are made up of molecules. Some parts are combined into systems that are specialized to carry out a particular function. For example, cells in multicellular organisms combine to form tissues that make up organs that carry out a specific function. Parts and wholes and their functions is a recurring concept in life science that begins with young children learning about external parts of familiar organisms and builds through successive grade levels culminating in understanding the parts of cells that carry out chemical reactions or contain genetic information, and the biomolecules involved.

One of the disciplinary core ideas in A Framework for K-12 Science Education is LS1.A Structure and Function (NRC 2012). This disciplinary core idea is included in the Next Generation Science Standards (NGSS), which state that grade 1 students are expected to use the

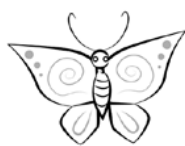
idea that "all organisms have external parts. Different animals use their body parts in different ways to see, hear, grasp objects, protect themselves, move from place to place, and seek, find, and take in food, water, and air. Plants also have different parts (roots, stems, leaves, flowers, fruits) that help them survive and grow" (NGSS Lead States 2013, p. 12). The formative assessment probe "Is It Made of Parts?" (Figure 1) is designed to uncover K-2 children's initial ideas about the parts of organisms (Keeley 2013). The teacher can then use this assessment information to make informed decisions about scaffolding the instructional opportunities children will need to develop a foundational understanding of the relationship between structure and function.

\section{Using the Probe}

To scaffold this "structure and function" probe for assessment purposes, begin by identifying the sub-ideas that this formative assessment probe can uncover at the $\mathrm{K}-2$ level. These sub-ideas for formative assessment include:

1. Recognizing that all organisms have parts (with a focus on the external structures, not internal structures),

2. Describing how animals use their body parts,

3. Identifying parts of a plant, and
4. Describing basic functions of plant parts (to survive and grow).

The probe is purposefully designed to uncover these sub-ideas using the organisms and parts of organisms in the pictures. Starting with sub-idea 1 , notice that the language of the probe uses "parts," not structures. Later, children will learn that parts of living things are referred to as structures, but first it is best to start with the familiar terminology. Also notice that the examples are plants and animals or parts of plants and animals in order to develop the generalization that all organisms have parts. In some of the examples, the parts are obvious; in others, they are not obvious.

Begin by having children choose the things on the list that are made of parts and describe the "rule" they used to decide if they are made of parts. Some of the typical responses from primary age children include: if there are arms or legs; if there are eyes, ears, noses, or mouths; and if it doesn't all look the same. Probing further you might find that students fail to include the worm as it doesn't have the familiar body parts. Or they may fail to recognize that the snake has parts if their rule is that it has to have arms or legs, even though it has a head, eyes, and so on. Some may not include the leaf or feather because it is a part of something else and the 
seed looks the same all around. All of this information can be used to design a lesson on external "parts and wholes" to show how plants and animals have a variety of different parts and their parts are also made up of smaller parts. If students are still stuck on the earthworm and the seed, have them observe real earthworms and seeds, using magnifying devices, to see different parts. They might see that a seed has an outer coat or a part where the seed attached to the plant. They might notice the segments on an earthworm, the light-colored band (clitellum), and sometimes they may even see the bristles on a large earthworm or the mouth opening if they use a magnifying lens. This might be a time to find a children's book about earthworms that shows the external structure of an earthworm. Listen carefully for evidence of how their initial ideas about parts of organisms are changing as they are confronted with their ideas. Add additional organisms and parts of organisms to further challenge, refine, and solidify their thinking. This information will help you determine the extent to which students can use sub-idea 1 .

After students recognize that all of the organisms listed on the probe have parts, and that some of the examples are parts of organisms, it is time to assess sub-idea 2: how they connect parts (structure) to uses (function), beginning with animals. Ask them which things on the list are animals or parts of animals (note that some children may not consider a person, worm, butterfly, or snake to be an animal if their concept of an animal is limited to mammals which indicates the need to develop the precursor idea of "animal"). Start-

\section{FIGURE 1.}

"Is It Made of Parts?" formative assessment probe.

\section{Is It Made of Parts?}

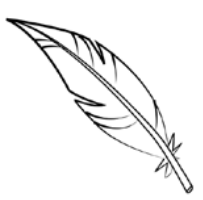

feather

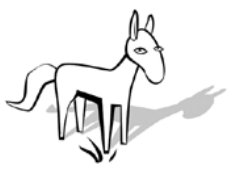

horse

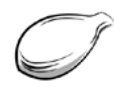

seed

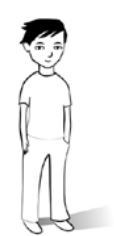

person

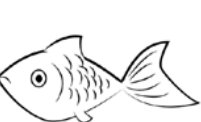

fish

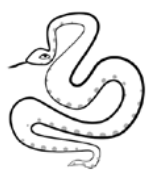

snake

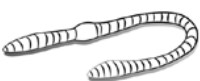

worm

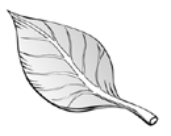

leaf

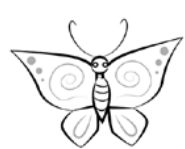

butterfly

\section{What are you thinking?}

ing with the whole organisms, have the children point out the different parts of the animals on the list (person, horse, fish, snake, butterfly, and worm) and ask them what they think the animal uses that part for. Start with a familiar animal like the person or the horse and then move to the other animals on the list. They might not know what the parts of an earthworm are called or what they do, but give them an opportunity to share what they think the parts do for the worm. Probe further by asking them which parts of the animals help the animal see, hear; grasp objects; protect themselves; move from place to place; and seek, find, and take in food, water, and air. As their ideas are developing, add examples of animals 


\section{Formative Assessment}

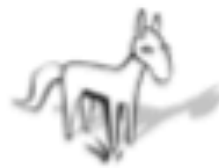

to probe further and comine their thinking about functions of animal parts. Then move to the feather and ask them if that is as animal of a part of an animal. If students recognize that a feather is a part of a bind, ask them what the bind usea iss feathers for. Probe further to see if they resognize that a part of an animal (a feather) is made of parts Have a feather wnilable for students to cbarve. For example, stubents might notice the many barbs of the feather that join together to make up the blade of the feather

Now that you have information about students' ideas related to sub. idea 2 - the uses (function) of animal parts (structures), and have informed your instruction to develop and so. lidify these ideas, you can move on to sub-idea 3 . Shos students an ac. tual plant or picture of a plant. Ask them, "If animals have partas do plants also have parta?" Provide them with an opportunity to point out and name the plant parts they can see. Ask them which $\alpha$ amples in the pictures are parts of plants (leaf and sced). Have them name other parts of plants that aren't in the pictures, guiding them toward roots, flow. er, fruit, and stem if they bave not already mentioned these. The information reveals which parts they are familiat with and which parts they may noed mare cpportunities to ebeerve and discuss

The last sub-ide has students connect the plant parts to their func. tians, without going iato detailed plant processes at this level, such as photosynthesis. Ask them what they think the leaf and soed are used for. Linten carefully to we if they recognite that plants need sunlight to grow and the leaf helps the plan: "get" manlight. Listen for early idess about reproduction, mach as meeds are used to grow moee plants. Extend the probe to include cther plant parts in this wab-ides wach as roots, stems. Bowers, and fruits.

The "Is it Made of Parts" probe is an example of scaffolded foemative assessment. Using a formative asessment probe to dicit each of the sub-ideas that make up a learn-

ing goal provides valuable informa tien that a teacher cas then use bo design instruction that builds upon and links sub. ideas, while simul.

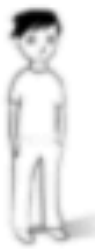
taneously peomot.

ing student thinking. As you use any of the formative asaessment probes in the Uncovering Student ldeas wries. think about hos you can break any learming groal down into a smaller aet of ideas that you can use to scaffald asesament and inatruction.

Pay Keeley (pkecleyan mmsa.erg) is the auther of the Uneovering Student Ideas in Science series (htips//uneoveringstudentideas. arg] and a former NSTA president.

Referances

Keelexp P. 2013. Uheowring studbute dideds in penimdry science 25 new Somative aseasement probes Arliegten, Wa NSTA Press.

Netional Reseurch Counel (NaC) 2012. A frumewark for $K-12$ mence edveation Proctices, eroscutting cencrets, ard core iuses Wenhingten DC: Nutienal Acodemies Press.

NGS5 leod Stores. 2013. Next Cerergtion Soinces Stendords: For states, by stabas. Wastington DC: Notional Aondemies Press mow nextgenscience ory/nentgenerabon. scimctestendarch

NSTA Connection Download the "Is it Made of Ports?" probe at mow.nsta.arg/ $5 \mathrm{C}+312$. 
Dear Teacher,

Thank you for participating in Tryon Creek State Park's Field Trip Program. The Friends of Tryon Creek is working to align their Field Trip programs with the Next Generation Science Standards (NGSS), the most recently developed set of standards that will guide $\mathrm{K}-12$ schools in the United States in the areas of science. In 2014, Oregon became one of sixteen states that have adopted the NGSS. A clear and concise introduction to these three dimensions can be found here: http://www.bozemanscience.com/next-generation-science-standards-introduction

What sets the NGSS apart from previous science standards is that students need to integrate three dimensions - Disciplinary Core Ideas, Crosscutting Concepts, and Science and Engineering Practices - in order to be scientifically literate. In doing so, students will be able to connect science to the real world and develop a conceptual understanding of how science works. The NGSS Performance Expectations (PE) combine the three dimensions. Each PE is a set of goals that reflects what students must know and be able to do by the end of a certain grade level. Another unique aspect of the NGSS is that the PEs build upon each other coherently from grade level to grade level. It is the role of educators to decide what Disciplinary Core Ideas, Crosscutting Concepts, and Science and Engineering Practices students need to know and be able to do in order to achieve the PE by the end of the year.

This field trip program aims to support the following NGSS Performance Expectations by developing a deeper understanding of how plants and animal parts (structures) allow them to live (function) successfully in the Tryon forest:

K-LS1-1 Use observations to describe patterns of what plants and animals (including humans) need to survive.

1-LS1-1 Use materials to design a solution to a human problem by mimicking how plants and/or animals use their external parts to help them survive, grow, and meet their needs.

2-LS2-2 Develop a simple model that mimics the function of an animal in dispersing seeds or pollinating plants.

The program will provide a model of how a lesson can integrate the three dimensions of the NGSS. During your class field trip, the program will focus on teaching the Disciplinary Core Idea and Crosscutting Concept of Structure and Function; and the Science and Engineering Practices of Developing and Using Models and Constructing Explanations. Attached to this email is the Field Trip Program Outline that will be used during your class visit. Please review it to get a sense of how the three dimensions will be integrated. 
In preparation for your class field trip, the "Is It Made of Parts" probe (attached) can be used as a pre-activity in your classroom to set the stage for your students' experiences during the Field Trip Program. In addition, we have created a lesson template that can help you develop a follow - up activity in the classroom. This site can help you design a lesson that integrates the three dimensions of NGSS: http://rgss.nsta.org/designing-units-and-lessons.asgx

We are determined to improve our programs. As a step towards improvement, we are conducting research to learn how our Field Trip Program helps teachers understand the three dimensions of the NGSS. After the field trip, you will receive an email with the option to complete an online survey. Upon completion of the online survey, you will be given the option to participate in a follow-up interview which will be conducted by Noelle Niedo, a PSU graduate student, at a location and time convenient for you. Both online survey and interview will take approximately 30 minutes each to complete.

Your feedback is valuable to improving our programs. Should you participate, you will receive a compensation of:

- One $\$ 25$ Amazon gift card for participating in the online survey

- An additional Amazon $\$ 25$ gift card for participating in the interview

Please feel free to contact Noelle at noelle2 9 pdx.edu with any questions regarding the program and/or research option.

We look forward to providing an engaging and educational program for you and your students during your time at Tryon Creek State Park. 


\section{Appendix B: Measurement Instruments}

\section{Invitation to participate in the Understanding of the Three Dimensions of the Next Generation Science Standards Study}

As a K-2 Teacher who participated in Tryon Creek's Fieid Trip Program, you are irvited to participate in a research study conducted by researchers at Portland State University. We hope to leam how the field trip program helped you te understand the three dimensicns of the Next Gereration Science Standards (NGSS). You were selected as a participant for this research based on your participation in Tryon Creek's Field Trip Procram.

Participation is voluntary. By agreeing to participate in this research, you will have the coportunity to proceed to the online survey. Upon completion of the orline survey. you will be given the option to participate in a follow-up interview. which will be conducted by a PSU graduate student at a location and time converient for you. If no consent is given, you will not be directed to the online survey.

Your feedback is valuable to improving our programs. Should you participate, you will receive a compersation of One \$25 Amazon gift card for participating in the coline survey

An additional \$25 Amazon gifl card for participating in the interview

Are there any risks? Your participation is voluntary. If you decide not to take part in this study it will not aflect your relationship with Tryon Creek State Park, your school district, or Portland State University. If you decide to participate in the study, you may withdraw your consent at any time, without penalty. By participating. you ane not waiving any legal claims, rights, of remedies.

What are the benefits? This study is designed to provide information that may help informal education programs to betier serve the needs K-12 teachers and students. As a participant in this project your consent to the research can cortribute to the stucy of the role of informal science education programs on teacher professional cevelopment and how to best support teacher understanding of the Next Generation Science Standards.

What are you doing to protect me? All information that is obtained in study that can be linked to you or identfy you will be kept confidential. Before any analysis is performed in this study, your name will be replaced with a randornly assigned number. All information and data collected in this study will be kept in a locked file cabinet at the Portland State University Center for Science Education curing the study where only research stalf will have access. Af:er the study is complete, all information will be safely stored in the office of the Center for Science Education for a period of three years.

Who can I eall with questions? If you have concerns or problems about your participation in this study or your rights as a research subject, please contact the Human Subjects Research Review Committee, Otfice of Research anc Strategic Partnerships, Market Center Building, 1600 SW 4th, Portland State Uriversity. (503) $725-3423$ or (800) S478887. If you have questions about the study itself, contact the PSU graduate student researcher, Noelle Necto, at the Center for Science Education, (503) 801-5531, ncele2) Epdx.edu.

Please indicate your decision by checking one of the options. If you change your mind later, please contact the researcher or the Human Subjects Research Review committee at the number above. your email address below. (optional) 
Please provide your name. Your identity will be kept confidential. All names will be removed and data will be aggregated in ways that protects your personal connection to your answers.

First Name

Last Name

Thank you for participating in our survey. We would like to know the following information about you.

Your scheol this year

Grade level you are teaching this year

Number of years you have been teaching

Please tell us your personal educational beckeround in science (i.e. high school, colege classes. major, PD)

Please tell us what training you have received to help you prepere to teach Next Ceneration Science Standards-aligned science

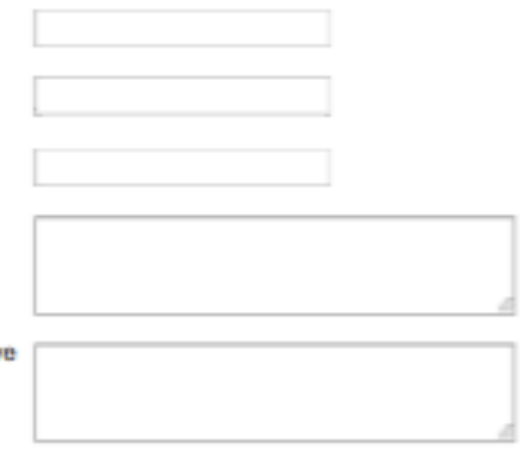

For the following questions, please check all answers that apply.

Did you read the introductory letter which was emailed before the field trip? Read before the field trip

Did you watch the Next Generation Science Standards Introduction video?

Did you read the Field Trip Program Outline?

Read before the field trip Read after the field trip Did not read


Did you use the Is It Mace of Parts probe as a class activity?

Did you use the Lesson Template to help design a classroom follow-up activity?

Yes $\quad$ No

Did you use the Desigring Units and Lessons webpage to design a classroom follow-up activity?

Yes No No

In the following sections, we would like you to compare how you felt before the field trip and after the field trip. The "field trip" is defined as when you received the email and materials we sent regarding the Next Generation Science Standards and the field trip experience itself.

I am aware that the Next Generation Science Standards (NGSS) has three dimensicns of learring

\begin{tabular}{|c|c|c|c|c|c|}
\hline & $\begin{array}{l}\text { Strengly } \\
\text { Disagree }\end{array}$ & Disagree & Neutral & Agree & Strongly Agree \\
\hline Before the feld trip & 0 & 0 & O & O & 0 \\
\hline After the field trip & 0 & 0 & $\mathrm{O}$ & 0 & 0 \\
\hline
\end{tabular}

I am aware of what an NGSS Performance Expectation is.

\begin{tabular}{|c|c|c|c|c|c|}
\hline & $\begin{array}{l}\text { Strongly } \\
\text { Disagree }\end{array}$ & Disagree & Neutral & Agree & Strongly Agree \\
\hline Before the field rip & 0 & $\mathrm{O}$ & $\mathrm{O}$ & O & $\mathrm{O}$ \\
\hline After the field trip & 0 & 0 & 0 & O & $\mathrm{O}$ \\
\hline
\end{tabular}

I am aware that NGSS Performance Expectations are not curriculum.

\begin{tabular}{l|lccc}
\hline & $\begin{array}{c}\text { Strongly } \\
\text { Disagree }\end{array}$ & Disagree & Neutral & Agree Strongly Agree \\
\hline Before the field vip & 0 & 0 & 0 & 0 \\
After the field trip & 0 & 0 & 0
\end{tabular}

I am aware the NGSS Performance Expectations are a set of goals that reflect what students must know and be able to 
do by the end of a certain grade level.

\begin{tabular}{l|l|l|l}
\hline $\begin{array}{l}\text { Strungly } \\
\text { Disagree }\end{array}$ & Disagree & Neutral Agree & Strongly Agree \\
\hline Before the field vip & & & 0
\end{tabular}

I am aware that there are more Disciplinary Core Ideas, Crosscutting Concepts, and Science and Engineering Practices than what was modeled curing the field trip.

\begin{tabular}{l|cccc} 
& $\begin{array}{c}\text { Strongly } \\
\text { Disagree }\end{array}$ & Disagree & Neutral & Agree Strongy Agree \\
\hline Before the feld trip & 0 & 0 & 0
\end{tabular}

\section{Block 2}

I am aware of the Disciplinary Core Idea of Structure and Function.

\begin{tabular}{l|cccc}
\hline & $\begin{array}{c}\text { Strongly } \\
\text { Disagree }\end{array}$ & Disagree & Neutral & Agree Strongy Agree \\
\hline Before the field vip & & 0 & 0 & 0 \\
After the field trip & 0 & 0 & 0
\end{tabular}

I can help my students understand the Disciplinary Core Idea of Structure and Function.

\begin{tabular}{|c|c|c|c|c|c|}
\hline & $\begin{array}{l}\text { Strangly } \\
\text { Disagree }\end{array}$ & Dsagree & Neusral & Agree & Strongy Agree \\
\hline Before the feld vip & & 0 & 0 & O & \\
\hline After the fieid trip & & 0 & & 0 & \\
\hline
\end{tabular}

I can help my stucents recognize that all organisms have external structures.

\begin{tabular}{|c|c|c|c|c|c|}
\hline & $\begin{array}{l}\text { Strengly } \\
\text { Disagree }\end{array}$ & Disagree & Neutral & Acree & Strongy Agree \\
\hline Before the field trip & 0 & O & $\mathrm{O}$ & 0 & O \\
\hline After the field trip & & & & (7) & \\
\hline
\end{tabular}

I can help my stuctents recognize that all organisms are made of parts.

\begin{tabular}{|c|c|c|c|c|c|}
\hline & $\begin{array}{l}\text { Strongly } \\
\text { Disagree }\end{array}$ & Dsagree & Neusral & Agree & Strongy Agree \\
\hline Beffere the fold tris & $n$ & $\Omega$ & $O$ & n & $\mathrm{O}$ \\
\hline
\end{tabular}

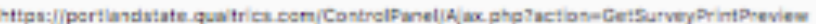


After the field trip

I can help my students recognize that the function of an object or organism determines its structure.

\begin{tabular}{l|lccc}
\hline $\begin{array}{c}\text { Strongly } \\
\text { Disagree }\end{array}$ & Disagree & Neutral & Agree \\
\hline Before the field vip & 0 & 0 & 0
\end{tabular}

I can help my stucents understand that cifferent animals use their extemal parts in different ways to survive, grow, and reproduce.

\begin{tabular}{|c|c|c|c|c|c|}
\hline & $\begin{array}{l}\text { Strongly } \\
\text { Disagree }\end{array}$ & Disagree & Neutral & Agree & Strongly Agree \\
\hline Before the feld trip & 0 & $\mathrm{O}$ & $\mathrm{O}$ & 0 & $\mathrm{O}$ \\
\hline Afler the field trip & 0 & 0 & O & & 0 \\
\hline
\end{tabular}

What part of the field trip helped you most to understand the Disciplinary Core idea of Structure and Function?

Block 3

I am aware of the Crosscutting Concept of Structure and Function.

\begin{tabular}{|c|c|c|c|c|c|}
\hline & $\begin{array}{l}\text { Strengly } \\
\text { Disagree }\end{array}$ & Disagree & Neusral & Agree & Strongy Agree \\
\hline Before the field trip & 0 & 0 & 0 & 0 & 0 \\
\hline After the field trip & & 0 & 0 & & O \\
\hline
\end{tabular}

I can help my students recognize that they will see structure and function in different aneas of disciplinary content (Physical Science, Life Science, Earth and Space Science, and Engineering).

\begin{tabular}{l|ccccc} 
& $\begin{array}{c}\text { Strongly } \\
\text { Disagree }\end{array}$ & Disagree & Neural & Agree & Strongy Agree \\
\hline Before the field trip & 0 & 0 & 0 & 0 \\
After the field trip & 0 & 0 & 0 & 0
\end{tabular}


I can help my stucents recognize that both natural and human-built systems have structures that are related to specific functions.

\begin{tabular}{l|ccccc} 
& $\begin{array}{c}\text { Strongly } \\
\text { Disagree }\end{array}$ & Disagree & Neutral & Agree & Strongy Agree \\
\hline Before the field vip & 0 & 0 & 0 & 0 \\
Afler the field trip & 0 & 0 & 0 & 0
\end{tabular}

\section{Block 4}

I can help my stucents recognize that engaging in the Practices of Science and Engireering allows them to understand how scientific knowiedge develops.

\begin{tabular}{l|ccccc}
\hline & $\begin{array}{c}\text { Strongly } \\
\text { Disagree }\end{array}$ & Disagree & Neutral & Agree & Strongly Agree \\
\hline Before the field vip & 0 & 0 & 0 & 0 & 0 \\
After the field trip & 0 & 0 & 0 & 0
\end{tabular}

I am aware of the Science and Engineering Practice of Constructing Explanations.

\begin{tabular}{l|ccccc}
\hline & $\begin{array}{c}\text { Strongly } \\
\text { Disagree }\end{array}$ & Disagree & Neutral & Agree & Strongy Agree \\
\hline Before the feld trip & 0 & 0 & 0 & 0 & 0 \\
Afler the field trip & 0 & 0 & 0 & 0
\end{tabular}

I am aware of the Science and Engineering Practice of Developing and Using Models.

\begin{tabular}{l|ccccc} 
& $\begin{array}{c}\text { Strongly } \\
\text { Disagree }\end{array}$ & Disagree & Neutral & Agree & Strongy Agree \\
\hline Before the field trip & 0 & 0 & 0 & 0 & 0 \\
Afler the field trip & 0 & 0 & 0 & 0 & 0
\end{tabular}

Which of the following activities did you see during the field trip? Check all that apply.

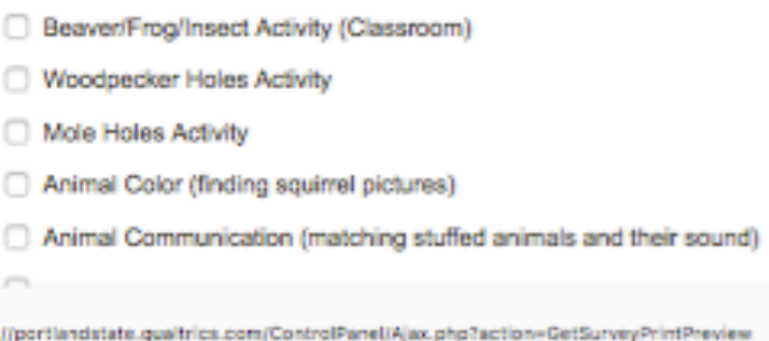


Seed Activity (hazeinut)

Plant Protection (therns en stinging nettie)

Creab-a-Creabure Activity

I did nat see ary of these activities.

The Science and Engineering Practice of Devoloping and Using Models allows students to engage in using a model to represent relationships. Through this practice, studerts also distinguish between a model and the actual object the model represents. Of the activities you observed, which activity incorpcrated the Science and Engineering Practios of Devoloping and Using Models? Chock all that apply.

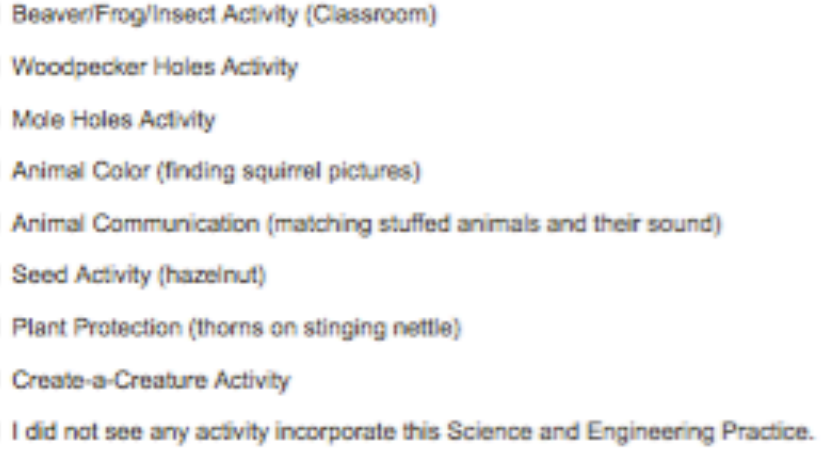

The Science and Engineering Practice of Constructing Explanaticns allows students to engage in using information from cbservations to construct an evidence-based acoount for natural phencmena. Or the activifes you cbservec. which activity incorpcrated the Science and Engineering Practice of Corstructing Explanations? Check all that ancly

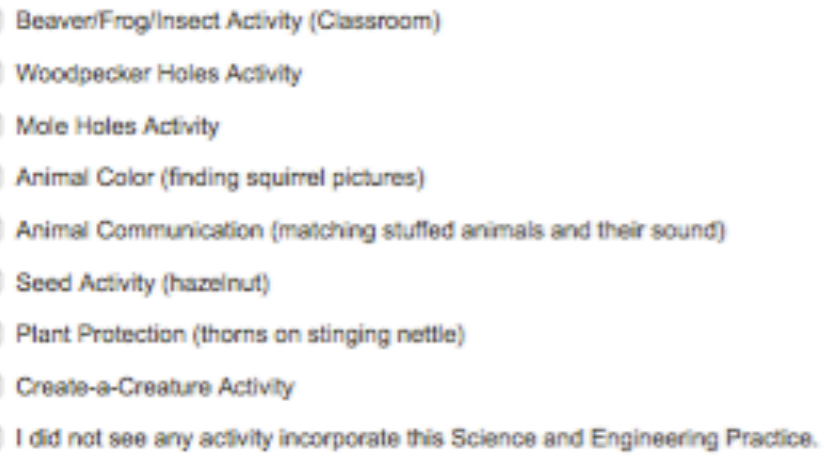

I can engage my students in the Science and Engineering Practice of Developing and Using Models.

$\mid \begin{array}{ccc}\text { Strongly } \\ \text { Disagree } & \text { Disagree Neutral Agree }\end{array}$


I can engage my students in the Science and Enginearing Practice of Constructing Explanafions.

\begin{tabular}{|c|c|c|c|c|c|}
\hline & $\begin{array}{l}\text { Strengly } \\
\text { Disagree }\end{array}$ & Dsagree & Neusral & Agree & Strongy Agree \\
\hline Before the field trip & 0 & 0 & $\mathrm{O}$ & 0 & 0 \\
\hline Afler the fieid trip & & 0 & 0 & O & $\mathrm{O}$ \\
\hline
\end{tabular}

How useful do you think each of these materials was in helping you understand the NGSS? Your feecback will help us improve our programs in the future.

\begin{tabular}{|c|c|c|c|c|c|}
\hline & Didnt read & Not at all useful & Not very useful & $\begin{array}{l}\text { Somewhat } \\
\text { useful }\end{array}$ & Very usetul \\
\hline Introductery Letter (emai) & & 0 & & & \\
\hline $\begin{array}{l}\text { Next Generation Science } \\
\text { Standards Introduction Video }\end{array}$ & & $\infty$ & & & \\
\hline Field Trip Program Outine & & & & & \\
\hline Is 7 Made of Parts Probe & 0 & $\mathrm{O}$ & 0 & & O \\
\hline $\begin{array}{l}\text { Lessan Template for } \\
\text { classfoom follow-up activily }\end{array}$ & & & & & \\
\hline $\begin{array}{l}\text { Designing Units and Lessons } \\
\text { Webpage }\end{array}$ & 0 & $\mathrm{O}$ & 0 & 0 & C \\
\hline $\begin{array}{l}\text { Field Trip Experience at } \\
\text { Tryon Creek State Park }\end{array}$ & & & & & \\
\hline
\end{tabular}

\section{Block 5}

If you were to design a follow-up activity for your class, how would you take what you learned during the fieid trip to develop that activity for your class? Please provide a detailed description. Be sure to include how you would incorporate all three NGSS cimensions: Disciplinary Core Idea, Crosscutting Concept, and Science and Engineering Practice.

What did you observe on the field trip that helped you understand integrating the three NGSS dimensions (Disciplinary Core Idea, Crosscutting Concept, and Science and Engineering Practice) into teaching science? 
What other activities have you planned or will plan in your cumiculum during the year that buld student understanding of the Crosscutting Concept of Structure and Function?

What other information would be helptul for you to better understand using the NGSS?

Block 6

Block 1

Thank you for participating in the research survey. Please provide your email address so that a \$25 Amazon gift card can be sent to you via email.

Email Address

Interviews will be scheduled at a location and time convenient for you. Should you participate, you will receive a compensation of an additional \$25 Amazon gift card. Would you like to participate in a follow-up interview?

Yes No

Thank you again for participating in the research survey. This final section will serve as an evaluation for general aspects of the Field Trip Program. 


\begin{tabular}{|c|c|c|c|c|c|}
\hline & $\begin{array}{l}\text { Strongly } \\
\text { Disagree }\end{array}$ & Disagree & Neutral & Agree & Strongly Agree \\
\hline $\begin{array}{l}\text { My studems are better able } \\
\text { to meet my leaming } \\
\text { abjectives due to this } \\
\text { program }\end{array}$ & 0 & 0 & 0 & 0 & 0 \\
\hline $\begin{array}{l}\text { This program was } \\
\text { educational for my students }\end{array}$ & 0 & 0 & 0 & O & O \\
\hline $\begin{array}{l}\text { This program was fun for my } \\
\text { students }\end{array}$ & 0 & 0 & 0 & 0 & 0 \\
\hline $\begin{array}{l}\text { Our Nature Guides seemed } \\
\text { to understand children and } \\
\text { related to them wel }\end{array}$ & 0 & 0 & 0 & 0 & 0 \\
\hline
\end{tabular}

What would have improwed the program for you?

What was your favorite part of the program? 
Interview Questions

Interview Question 1: What materials did you receive in advance? Did you receive and engage in any material regarding the Next Generation Science Standards before the field trip?

Interview Question 2: Can you tell me where you saw or heard the Disciplinary Core Idea of Structure and Function at any point during the field trip?

Interview Question 3: The Science and Engineering Practice of Constructing Explanations involves using information from observations to construct an evidence based account for natural phenomena. Do you recall if there was a point in the field trip where your students were asked to construct their own explanations based on evidence they found?

Interview Question 4: Developing and Using Models in the K-2 level involves creating physical replica to represent phenomena and distinguishing between a model and the actual object the model represents. Do you recall if there was a point in the field trip where your students used a model to represent relationships? Or learned to distinguish between a model and the actual object the model represents?

Interview Question 5: Structure and Function is a concept found in all areas of science in both natural and human-built systems. Can you tell me where you saw or heard or saw this idea at any point during the field trip? 


\section{Appendix C: Interview Transcripts}

Interview Question 1: What materials did you receive in advance? Did you receive and engage in any material regarding the Next Generation Science Standards before the field trip?

- Teacher 6: It was actually just a ton of information that I received. And, I'Il be honest, I only went through part of it...

- Teacher 7: I didn't have a lot of time to read through things. my attitude was that I just had to get the kids ready. I think I might have gotten more emails that I didn't read. I don't recall [receiving any materials regarding the NGSS]. Maybe there was but I don't remember anything.

- Teacher 13: we did that "is it made of parts" probe assessment...and I even went on the NGSS website and looked at some of the resources they had.

- Teacher 17: I did [notice information about the NGSS in particular]. I did like the structure of having kind of the information ahead of time of what you guys were going to be talking about and being able to do some basic conversation about it and then see it and then we got into deeper conversation when we got home, then got back to school. 
Interview Question 2: Can you tell me where you saw or heard the Disciplinary Core Idea of Structure and Function at any point during the field trip?

- Teacher 6: I feel like, you know, when he was talking about the different beaks on the different birds... and he talked about what they're used for and what would this bird eat and things like that. We talked about, um, like a beaver's tail, and a beaver's claws, and its teeth...I think they were moles that were making all those holes. But we talked about, you know, how their claws worked and helped them in the hole and, you know, how fast they could dig the dirt, you know, and all that type of things. But they did the classroom activities. I feel like we talked about, you know, 'if your paw was formed like a spatula or a fork or those different things: which one was easier...?' So that kind of, you know, showed them. Although they already knew the results, you know, before we even did the "which one could pick up more cotton balls" or whatever, I don't really remember exactly.

- Teacher 7: I think in the classroom it was going on because the Tyron creek volunteer was talking to the kids about the beaver. And she was talking to them explicitly about the body parts of the beaver and how the body parts have adapted in a way for the beaver to survive. So there was a lot of conversation about the beaver's tail and how it flaps. And how it flaps, it's telling its children that there's danger. 
- Teacher 13: I felt like the pre-assessment helped me and I've been away of it before but never in those terms... so it was nice to have those terms there and even using those terms with my students I think is important...I felt like this was a really good background foundation for me to continue next year when we study animal adaptations and when we study plants just thinking about the form and the function of the different parts. and that ties right into our adaptation unit. so it's just nice to add those words into my sort of awareness and to also use those terms in different ways with my kids with our adaptions unit that we're going to do next year. We talked about it in the beaver activity. in the beaver activity, they talked about the different parts and what it was used for. the claws, the tail, the fur, we talked about the teeth and what the functions of that were...the beaver activity, that was a big part of it. And the trail, we definitely talked about the different parts like for example, the stinging nettle. we talked a lot about that. one of my kids actually did have a little bit of a sting. of course he touched it because he was curious. so we talked a little bit about that.

- Teacher 17: oh she pulled out the skull of the woodpecker and talked about how... and the tongue, how the tongue works.

Interview Question 3: The Science and Engineering Practice of Constructing Explanations involves using information from observations to construct an evidence based account for natural phenomena. Do you recall if there was a point in the field 


\section{trip where your students were asked to construct their own explanations based on}

\section{evidence they found?}

- Teacher 6: The seed dispersal definitely. Because they were so into that, yes. He would ask them questions: "How could this have gotten from point a to point b?" And they came up with a million ways: "A bird could take it, an animal could take it, it could stick on your fur," you know, "the wind," things like that. We also talked about the layers of the forest. And we had talked a lot about that at school and how dark it was, you know, where we were and then we could look up and could see that it was bright up above, and which animals would live up there and which were down on the forest floor, things like that.

- Teacher 7: Yes. Definitely. There was a lot of investigative kind of work that went on where they were asked, "well what do you think about that? or "what would you do if you were an animal" or "why do you think the plant has done that." yeah there was definitely... the guy that was our guide definitely, I think he was a high school teacher, so he definitely asked them some questions... kind of hypothesizing a little bit...

- Teacher 13: I think when they did the create their own animal they definitely had to explain, for sure. that was really a clear and obvious one. and then when we were doing the trail, I remember the guide, one of my kids would point out and notice a banana slug or notice a cone or notice something... a hole... and she would ask questions, for sure: "why do you think hat's that way? and what do 
you think that's for?" and so I totally remember she asking lots of questions and having the kids respond, absolutely, I couldn't tell you the exact questions or details but I do remember that exchange for sure. but it was most clear because every kid was busy and I could sit and really observe while the trail was the trail was a little bit more active for me.

- Teacher 17: I think during when they built their own animals. I think that was the only time. and why did you give it those wings? and what would that do for it? and I think those were the only ones that they really kind of gave their explanations. I mean they gave thoughts on things and asked questions. but I think that was the only time they were really giving their like...

Interview Question 4: Developing and Using Models in the K-2 level involves creating physical replica to represent phenomena and distinguishing between a model and the actual object the model represents. Do you recall if there was a point in the field trip where your students used a model to represent relationships? Or learned to distinguish between a model and the actual object the model represents?

- Teacher 6: (laughs) Yeah, well, his dead animals were good models - they were actually the real subject. But no, he did. He would just show us, you know, how little moles' paws kind of looked like a tiny fork. And then he had a fork and he dug through the dirt with that. And then the woodpeckers' beak, you know... he put it into a hole and showed them, you know, how deep it could actually go into a hole. And what would be inside the hole, things like that. In the classroom, we 
did the whole game, both of the games had the models... tools that we used that were not the true, you know, it wasn't a true claw but it was... I think one was like a spatula (representing) like a beaver's tail or something like that. And how fast it could go through water. And what it could do, things like that, yeah.

- Teacher 7: this guide did use some kind of. give me an example of what you mean. yeah. mhm. that's a really good idea. I don't remember seeing anything like that. there was models but that's really a good idea. that should definitely be added. I think we might have had conversion about the beak but I don't think. but you're right, kids need hands - on. they need to touch things and they need to be able to actually experience that wonder of "oh, so that's why that bird has such a long beak or " that's why that bird..." so and maybe the other guides may have talked about that more. I was only on one group. so the other guides might have definitely talked about it.

- Teacher 13: I think the beaver activity was definitely in line with the modeling because you know the guide was there and she would show an example of how to use the tongs or the spoon about making noise. she had that as a model for the kids to think about how they would use these different tools to communicate or to solve a problem or to build something. and so she used that modeling for sure. on the trail, I can't remember, I know when they had to build their own animal she started by doing something just to show. I think she grabbed one or two things nearby and just used that as an example because that was a pretty 
intuitive activity and the kids just got right to it, she didn't need to do much modeling there.

- Teacher 17: again, just that one time. but other than that, no. yeah, create a creature. yeah.

Interview Question 5: Structure and Function is a concept found in all areas of science in both natural and human-built systems. Can you tell me where you saw or heard or saw this idea at any point during the field trip?

- Teacher 6: Um, I don't - remember I didn't read them all. It was probably in there.

- Yeah. He did talk about the human built systems. I can't really think of what it was.

- I'm trying to think. I know that there probably were. And we did talk about like our hands and, um, you know, we looked at our own human hands and (discussed) "what are good for?" things like that, compared to animals' hands, and you know, "Are they webbed? Are they this? Tips of our fingers super sharp? No." You know, things like that. But I can' think of anything. No I just can't think of anything. I'm sure we discussed some things. He had a lot of knowledge. But I can' think of anything. No I just can't think of anything. I'm sure we discussed some things. He had a lot of knowledge.

- Teacher 7: I don't think so...I think it was probably brought up. I think it was brought up but I don't think it was brought up in those terms. I think it was simplified so that kids would understand it. but it was definitely addressed. 
because what you're talking about, again, is the body parts of the animal and the plants. or the parts. and you're talking about how they function in order to live in the ecosystem they are living in. so I think that was brought up quite a bit but it's almost like I need to understand that a little bit more myself.

- Teacher 13: well I felt like the engineering part was when we created our own animal on the trail part because that's when they were designing and building their own animals and I had quite a few kids building 2 or 3 different animals or had a team of kids building one big animal and then talking about the different parts. I felt that that was engineering, wouldn't you say that's correct? we talked about it in the beaver activity. in the beaver activity, they talked about the different parts and what it was used for. the claws, the tail, the fur, we talked about the teeth and what the functions of that were...the beaver activity, that was a big part of it. and the trail, we definitely talked about the different parts like for example, the stinging nettle. we talked a lot about that. one of my kids actually did have a little bit of a sting. of course he touched it because he was curious. so we talked a little bit about that.

- Teacher 17: we didn't really touch on that. I'm trying to think. I'm trying to recall. and I mean, I think a little of that applies in the classroom. I mean talking about the differences in our hands so I think when I think of the CCC, I think the most we saw of that was in the classroom when we were doing those. I felt like all of 
the guides in there were kind of using that, "how is that different from how you are and how is that..." I felt that there was more of that there. 